DARIUSZ ŁUKASIEWICZ

Instytut Historii im. Tadeusza Manteuffla PAN

\title{
SARMATYZM I PRUSY W XVIII I POCZĄTKU XIX WIEKU
}

Zarys treści: Historia polsko-pruska oceniana była dotąd z perspektywy obronnej, wyniesionej z czasów rozbiorów. Prowadziło to do typowej we wrogich relacjach przesadnej diabolizacji przeciwnika. Diabolizacja umiarkowana była już bardziej uzasadniona. Pruskie działania modernizacyjne były lekceważone albo przemilczane. W końcu jednak pojawiła się historiografia modernizacyjna, do której należała nawet konserwatywna szkoła krakowska, ale i endeckie, a wiec modernizacyjne pisarstwo historyczne Władysława Konopczyńskiego i Adama Skałkowskiego, ukazujące Sarmatyzm jako feudalny anachronizm i modernizację absolutystyczna, a więc odgórna w Prusach (von oben). Ten nurt utrzymuje się w historiografii do dzisiaj, jednak funkcjonuje też częsta multikulturowa perspektywa odrębności, inności, a nie niższości Sarmatyzmu.

Autor uważa za konieczne weryfikację tego stanu rzeczy i charakterystykę działań reformatorskich, dzięki którym w 1918 r. dystans między poziomem rozwoju cywilizacyjnego ziem zaboru pruskiego i rosyjskiego od $1793 \mathrm{r}$. bardzo wzrósł. Następnie wskazuje na kilka elementów takiej analizy.

The content outline: The Polish-Prussian history has traditionally been evaluated from the defensive point of view rooted in the times of the partitions. This led to excessive demonisation of the opponent, typical for hostile relations. Moderate demonisation of Prussia, however, was more justified. Prussian modernisation undertakings were either disregarded or ignored. Eventually, however, this trend changed thanks to the emergence of modernisation historiography, which could even be observed in the traditionally conservative Kraków School or the national democratic, and therefore modernisation-oriented, historical writings of Władysław Konopczyński and Adam Skałkowski, presenting Sarmatism as feudal anachronism and describing the absolutist - and therefore imposed from above (von oben) - modernisation in Prussia. This trend is still present in today's historiography, but Sarmatism is also often seen from a multicultural perspective that focuses on individuality and otherness, and not on inferiority. 
The author believes it necessary to verify this state of affairs and describe the reforms thanks to which the discrepancy between the level of civilisation development of the Prussian and Russian partition in 1918 increased significantly in comparison to the year 1793. He then indicates a number of elements of such analysis.

Słowa kluczowe: Sarmatyzm, absolutyzm oświecony, klientela, poddaństwo

Keywords: Sarmatism, enlightened absolutism, clientage, servitude

9 listopada 2013 r. ukazał się w magazynie „Gazety Wyborczej” bardzo znamienny wywiad z profesorem Janem Sowa, antropologiem kultury z Uniwersytetu Jagiellońskiego, na temat Polski sarmackiej. ${ }^{1}$ Autor głośnej książki Fantomowe ciało króla przedstawia tam tezę uznającą Polskę sarmacka, rozumiana jako swoista formacja kulturowa i cywilizacyjna, za twór wsteczny, reformy czasów stanisławowskich za powolne i rachityczne, a rozbiory za przyczynę przyśpieszenia procesów modernizacji na ziemiach polskich. Nie różnicuje przy tym zaskakująco rozbiorów na mniej i bardziej rokujące. Tymczasem w oczywisty sposób przyśpieszona modernizacja miała miejsce wyłącznie w zaborze pruskim, co stało się jasne w 1918 r., w różnicy w poziomie i jakości życia w dawnym zaborze pruskim i rosyjskim. Jak uważa Jan Sowa, Polska została rozebrana, bo nie potrafiła się dostosować do „porządku westfalskiego”. Trzeba chyba jednak powiedzieć inaczej - w XVII w. zaczyna się proces modernizacji cywilizacyjnej Zachodu, w tym instytucji publicznych, wprowadzanie nowoczesnej biurokracji, ustroju gospodarczego i społecznego, systemu podatkowego, armii, ale i szkolnictwa, służby zdrowia, opieki społecznej, miar, wag, systemu monetarnego bankowego, ubezpieczeniowego i bardzo dużo - i tak dalej, bo była to lawina zmian². A nie wiadomo, co ważniejsze, wszystko tak bardzo ważne. Na przykład laicyzacja legitymizacji władzy, samego państwa, systemu karnego, trochę zmiany stosunku do kobiet, wprowadzenie równości wobec prawa, eliminacja skrajnego myślenia średniowiecznego

1 „Gazeta Wyborcza”, Magazyn, 9 XI 2013; J. Sowa, Fantomowe ciało króla. Peryferyjne zmagania z nowoczesna forma, Kraków 2011.

${ }^{2}$ D. Łukasiewicz, Modernizacja przed modernizacja. Próby reform cywilizacyjnych $w$ Prusach Południowych w latach 1793-1806, ,Studia Historica Slavo-Germanica” 26, 2006, s. 41-78; tenże, Polacy i Prusacy w 1800 r., w: XVI Powszechny Zjazd Historyków Polskich. Przełomy w Historii. Pamiętnik, t. 2, cz. 1, Toruń 2000, s. 235-255; tenże, Szkolnictwo w Prusach Południowych (1793-1806) w okresie reform oświeceniowych, Poznań 2004. 
wprawdzie niezawinionego - likwidacja tortur, polowań na czarownice, kary śmierci dla homoseksualistów i samobójców. Z wolna w Europie powstaje nowoczesny, światły świat. Wydaje się konieczne wyjaśnienie, jak doszło do absurdalnej sytuacji, w której te proste i dosyć oczywiste sprawy wymagaja jeszcze obecnie wyjaśnień i tłumaczeń, i to przedstawianych w tak ostrożny i delikatny sposób, aby nie urazić czytelnika przekonanego, że rozbiory przyniosły nam same nieszczęścia. Po wystapieniu Jana Sowy w „Do Rzeczy” wypowiedział się poznański profesor z Instytutu Historii PAN, Grzegorz Kucharczyk. Z aprobata zwrócił uwagę na równie negatywny stosunek do Sarmatyzmu Romana Dmowskiego, co widoczne jest jaskrawo w Myślach nowoczesnego Polaka, gdzie ten wskazuje na wsteczny charakter feudalizmu, anachroniczność szlachty i do pewnego stopnia pozytywny wymiar rozbiorów, które przyśpieszyły proces modernizacji, przede wszystkim w zaborze pruskim. Dmowski zauważał też wiodącą w przemianach rolę zaboru pruskiego, zarówno w zakresie zmian mentalnościowych i strukturalnych na ziemiach polskich ${ }^{3}$. Warto zauważyć, że samo pojęcie „Sarmatyzm” ma rodowód oświeceniowy. Po raz pierwszy użyte zostało w negatywnym znaczeniu w reformatorskim „Monitorze” z 1765 r., potem w dramacie Franciszka Zabłockiego Sarmatyzm z 1785 r. Ówcześnie używane było dla określenia zacofania i braku oświecenia, szczególnie w odniesieniu do prowincjonalnej szlachty. Pojęcie dyskutowane jest do dzisiaj, jednak ja w te spory nie wchodzę. Sama szlachta określała siebie mianem Sarmatów, a swój kraj jako Sarmację już w XVI w. ${ }^{4}$

\section{Odreagowanie rozbiorów przez historiografię}

Dosyć częste w ostatnich dziesięcioleciach wypowiedzi, że wzajemne stosunki historiografii niemieckiej i polskiej uległy normalizacji maja przede wszystkim charakter dyplomatyczny i polityczny, i są bardzo na wyrost, chociaż rzeczywiście poprawa jest widoczna i miała miejsce już przed 1989 r., dzięki pracom polsko-niemieckiej komisji podręcznikowej. W 1991 r. w Warszawie powstał też Niemiecki Instytut Historyczny5 ${ }^{5}$

${ }^{3}$ R. Dmowski, Myśli nowoczesnego Polaka, Wrocław 2002; G. Kucharczyk, Polityk nowoczesny, europejski i demokratyczny, „Do Rzeczy”, I 2014.

${ }^{4}$ M. Faber, „Sarmatismus. Die politische Ideologie des polnischen Adels im 16. und 17. Jahrhunderts", Freiburg im Breisgau 2013, mps, s. 2-3.

${ }_{5}$ R. Jaworski, Deutsche Ostforschung und polnische Westforschung in ihren historisch-politischen Bezügen, w: Deutsche Ostforschung und polnische Westforschung im Spannungsfeld von Wissenschaft und Politik, Osnabrück-Poznań 2002, s. 11-12. 
Do dzisiaj jednak w sporym stopniu historia ziem polskich pod zaborem pruskim była i jest $\mathrm{u}$ nas przedstawiana $\mathrm{z}$ punktu wiedzenia ofiar, jako ponure dzieje straszliwego nieszczęścia i dotkliwych szykan ze strony ciemięzcy i oprawcy. Ten tradycyjny dyskurs antyniemiecki, chociaż bardziej antypruski, kształtował się w toku ostrej, dramatycznej i śmiertelnej konfrontacji, zwłaszcza od lat 70. XIX w., w której to Polacy byli zarówno stroną słabsza, jak i poszkodowana, więc należy im się pełne zrozumienie ich emocji ${ }^{6}$. W Polsce używa się ostatnio pojęcia samomodernizacji dla ukazania twórczej roli ludności polskiej w rozwoju cywilizacyjnym. Jak pisze słusznie Lech Trzeciakowski: „W zaborze pruskim istniały warunki specyficzne. Prusy prowadziły politykę germanizacyjna. Z drugiej jednak strony, dążąc konsekwentnie do modernizacji państwa, stworzyły warunki dla różnych form aktywności społecznej”7. Dokładnie tak to wyglądało. „Władze były zainteresowane wzrostem cywilizacyjnym tych terytoriów”, jednak stanowiąca połowę ludność niemiecka była niesłychanie faworyzowana.

Jeszcze w XVIII i początkach XIX w. napotykamy na szereg pozytywnych ocen państwa pruskiego, czy ze strony Staszica, Kołłątaja, Lipskiego, Naruszewicza, Niemcewicza albo Surowieckiego, co nie znaczy, że nie postrzegali Prus krytycznie. Staszic radził naśladować fiskalizm pruski, ale i uważał Prusy za głównego wroga i pisał o „potworze, który żywi się pożeraniem Polski”. Warto zauważyć, że Księstwo Warszawskie budowane było na rusztowaniu instytucji pruskich. Ale Naruszewicz z kolei pisał krytycznie o Sarmatach: „Czegóż się błędny uskarżasz narodzie, los swój zwalając na obce uciski? Szukaj nieszczęścia w twej własnej swobodzie, i bolej na jej opłakane zyski. Żaden kraj cudzej potęgi nie zwabił, który sam siebie pierwej nie osłabił".

Wtedy jednak właśnie najsilniej kształtował się „negatywny obraz wroga”, jak to nazywa Roland Gherke ${ }^{9}$. Miał on przecież także funkcję integracji i budowania tożsamości wspólnoty przeciw złu i wobec zła. Metafora „nocy rozbiorów” trafnie oddaje klimat tego dyskursu

${ }^{6}$ A. Simsch, Die Wirtschaftspolitik des preußischen Staates in der Provinz Südpreußen 1793-1806/7, Berlin 1984, s. 38.

7 L. Trzeciakowski, Przedmowa, w: Samomodernizacja społeczeństw w XIX wieku. Irlandczycy, Czesi, Polacy, red. L. Trzeciakowski, K. Makowski, Poznań 1999, s. 10.

${ }^{8}$ H. Labrenz, Das Bild Preußens in der polnischen Geschichtsschreibung, Rheinfelden 1986, s. 29-35; M. Górny, Przede wszystkim ma być naród. Marksistowskie historiografie w Europie Środkowo-Wschodniej, Warszawa 2007, s. 176-177.

${ }^{9}$ R. Gherke, Das „räuberische Monstrum”. Preußen in der polnischen Historiographie des 19. und frühen 20. Jahrhunderts, w: „Thema Preussen” in Wissenschaft und Wissenschaftspolitik des 19. und 20. Jahrhudert, red. W. Neugebauer, Berlin 2006, s. 211-212. 
ofiar. Podczas metaforycznej „nocy” nic nie może się dziać dobrze, więc mało który historyk godzi się przerwać lawinę wyrzutów wobec wroga dostrzeżeniem jakiś pozytywów jego panowania. Taki był w każdym razie mainstream, który nadawał ton narracji na ten temat $\mathrm{w}$ sferze publicznej kraju i kulturze masowej. Motywem przewodnim narracji było niemieckie Drang nach Osten (po raz pierwszy Karol Szajnocha, 1859) oraz rabunkowy charakter ekspansji w duchu kolonizacji, potem bezduszność i amoralność oraz cyniczna polityka siły. W kulturze masowej odzwierciedlony był przez Krzyżaków Henryka Sienkiewicza (1901), Placówkę Bolesława Prusa (1885) i Rotę Marii Konopnickiej. Politycznie obraz pruskiego wroga został zdefiniowany w duchu socjaldarwinistycznym, a więc z naciskiem na pojęcia „walki” i „wroga”, przez Jana Ludwika Popławskiego, Zygmunta Balickiego i Romana Dmowskiego. Zarazem już w XVIII w. uznawano skuteczność i siłę Prus. Często oddzielano też dobre Niemcy od złego pruskiego rozbójnika (np. Stanisław Smolka). Ta sytuacja w znacznym stopniu trwa do dzisiaj ${ }^{10}$. Herbert Ludat zauważył nieco przesadnie, ale ogólnie słusznie, że w II RP nabrały mocy „optymistyczne” w ocenie własnego kraju tendencje kierowania badań ku okresowi piastowskiemu i jagiellońskiemu i narastał antyniemiecki charakter historiografii: „W niemal wszystkich dziedzinach historycy polscy uznali za swoja narodowa powinność zgłaszania zastrzeżeń wobec obowiązujących twierdzeń niemieckich"11.

Tak też do dzisiaj często uważa się, że wszystkie działania władz pruskich na ziemiach polskich podejmowane były w celu eksploatacji ekonomicznej Polaków i ich pauperyzacji, a potem degradacji wobec ludności niemieckiej sprowadzanej na ziemie polskie w ramach procesu kolonizacyjnego. Wynikać też miały z pogardy i wrogości będącej skutkiem nieprawdziwych negatywnych stereotypów religijnych, cywilizacyjnych i kulturowych. Były następnie konsekwencja wad ustrojowych, społecznych i politycznych samego państwa pruskiego, które miało charakter absolutystyczny, militarystyczny, wrogi katolicyzmowi, realizując interesy odgrywających wiodąca rolę junkrów. Były więc tworem anachronicznym i agresywnym, niesprzyjającym modernizacji z samej swej natury. Tragedia nazizmu i II wojny światowej wzmocniły

${ }^{10}$ D. Łukasiewicz, Preußische Exorzismen, in: Preußen - Erbe und Erinnerung, red. B. Kerski, Potsdam 2005, s. 139-150; A. Kamieński, Fryderyk II w polskiej historiografii, „Czasy Nowożytne”, t. 26, 2013, s. 99-101; R. Gherke, dz. cyt., s. 207, 211-212, 218, 222.

${ }^{11}$ H. Ludat, Dzieje stosunków polsko-niemieckich w oświetleniu marksistowskim, w: tenże, Stowianie / Niemcy / Europa. Wybór prac, Marburg-Poznań 2000, s. 276-277. 
$\mathrm{w}$ historiografii PRL-u negatywne tendencje interpretacyjne, czemu trudno się dziwić. Funkcjonowały one też w zwarciu i polemice $\mathrm{z}$ jednostronną i apologetyczna historiografią niemiecka. W rezultacie chętnie widziano nazistowskie korzenie juz $\mathrm{w}$ absolutyzmie XVIII-wiecznym ${ }^{12}$. Wprawdzie cały szereg argumentów negatywnych wobec Prus jest oczywiście uzasadnionych i nikt tego nie kwestionuje, problem w tym, że nie uwzględnia się albo pomniejsza pozytywne, i to o ogromnym znaczeniu. Jak pisze Herbert Ludat: „Cała energia polskiej nauki historycznej zwróciła się więc przeciw stronie niemieckiej i to z jeszcze większym impetem, niż po I wojnie światowej [...]. Tylko nieliczni historycy w tamtych czasach zdawali się zachowywać stosunkowo trzeźwy osąd historyczny - jak na przykład Kazimierz Tymieniecki, z jego wprawdzie zacieśniająca, ale też aprobującą oceną elementu niemieckiego, jako nośnika postępu w gospodarczej i społecznej przebudowie średniowiecznej Polski..."13 Całkiem nowy ton wypowiedzi i styl myślenia pojawił się po 1945 r. w historiografii marksistowskiej i znajdującej się pod wpływem marksizmu, której przedstawiciele uznali, że nie było żadnej odwiecznej, permanentnej i immanentnej wrogości polsko-niemieckiej, a konflikty i wojny wynikały jedynie z różnic interesów politycznych i ekonomicznych klas posiadających. Między zwykłymi Polakami występowała natomiast częsta, masowa i rozległa współpraca. Nawet tradycyjni historycy, jak Władysław Czapliński i Kazimierz Piwarski pod wpływem inspiracji marksistowskiej zwracali uwagę na anachroniczność obsesyjnego i przesadnego piętnowania polityki Hohenzollernów z perspektywy rozbiorowych doświadczeń. Wybitny historyk prawa Juliusz Bardach wskazywał na ważną rolę średniowiecznej kolonizacji niemieckiej jako impulsu modernizacyjnego, Roman Heck na pozytywna rolę niemieckiego mieszczaństwa, a Henryk Łowmiański widział kolonizację niemiecka jako element ogólnoeuropejskiego ruchu ku Zachodowi. Marksistowski przewrót końca lat czterdziestych jest interpretowany $\mathrm{u}$ nas zbyt prostodusznie i jednostronnie, a tymczasem oznaczał przecież także pojawienie się refleksji teoretycznej wykraczającej poza tradycyjny XIX-wieczny nacjonalizm ${ }^{14}$.

Te marksistowskie impulsy, jako narzucone przymusem, odegrały jednak w polskiej historiografii rolę dosyć niewielką. Zwykle pisarstwo historyczne szło jak wcześniej tradycyjnym torem pozytywistycznym

12 A. Sosnowska, Zrozumieć zacofanie. Spory historyków o Europę Wschodnia (1947-1994), Warszawa 2004, s. 334-335; H. Ludat, dz. cyt., s. 279.

${ }^{13}$ H. Ludat, dz. cyt., s. 279.

${ }_{14}$ Tamże, s. 283-286. 
i pozornie indukcyjnym ${ }^{15}$, gdzie działania modernizacyjne władz zaborczych były przedstawiane jako drugorzędne, ignorowane lub też ukazywane jako sposób narzucania nam „obcej” kultury. Jest to narracja nieakceptująca modelu modernizacji wiodącej rozwojowo od zacofanego feudalizmu do nowocześniejszego kapitalizmu, a wielość kultur, w której Sarmaci mieli prawo do własnej ścieżki rozwojowej. Nie rozwinęły się też w Polsce dostatecznie badania nad pruska problematyką cywilizacyjna, które głębiej i systemowo ujmowałyby zagadnienia szkolnictwa, przestępczości, infrastruktury, systemu fiskalnego, socjalnego, zdrowotności, problematyki mieszkaniowej, rodziny, religii etc. W rezultacie charakterystykę postaci Fryderyka II ujmowano z ogromną niechęcią i redukowano zwykle do kwestii rozbiorów. Wynikało to też z pogardy króla Prus wobec Sarmatów, co miało jednak charakter kulturowy, a nie etniczny i chłopom polskim współczuł, przyjaźnił się z biskupem Ignacym Krasickim oraz Marianną Skórzewska. Kazimierz Jarochowski emocjonalnie i redukując do aspektów polskich jego działalności, pisał o amoralności Fryderyka II i wrogości wobec religii. Pisał, że jego jedynym celem było powiększenie obszaru Prus, że lud był dla niego jedynie mięsem armatnim i płatnikiem podatków. Nie wspominał w ogóle o znanych przecież w całej Europie pionierskich, wielkich światłych i bardzo moralnych reformach prawa, w tym karnego, tylko o wtrącaniu się w drobne sprawy urzędnicze. Starania o poprawę przemysłu, handlu, rolnictwa były niegodne pochwały, bo spowodowane fiskalizmem. Reformy stanu chłopskiego dyskredytował, że za małe, a jak już były, wynikać miały z wyrachowania, bo chłopi byli producentami żywności i stanowili bazę rekruta dla armii ${ }^{16}$. Zarazem jednak potrafił krytycznie spojrzeć na znajdującą się na pruskim żołdzie polską magnaterię ${ }^{17}$.

Nie inaczej przecież wypowiadał się Wielkopolanin Kazimierz Zimmermann, który cytował wyłącznie niepochlebne wypowiedzi Stanisława Staszica o Prusach, a pozytywne pomijał. Relacjonując fryderycjańskie reformy wewnętrzne, Zimmermann nie dawał żadnych sądów wartościujących tam, gdzie konieczna była ocena pozytywna, a za to w dwójnasób wartościując negatywnie z potrzebą i bez potrzeby, atakując zaciekle szkolnictwo pruskie, które było w tym czasie najlepsze

${ }^{15}$ Czyli realne przesłanki ideologiczne i teoretyczne selekcji faktów i teorii były ukryte.

16 A. Kamieński, dz. cyt., s. 101-102.

17 Tenże, Kazimierz Jarochowski $i$ jego galeria Hohenzollernów, „Czasy Nowożytne”, t. 27, 2014, s. 106, 108-109. 
w Europie ${ }^{18}$. Warto jednak zauważyć, że równocześnie Zimmermann ostro atakował szlachtę polska za gnębienie chłopa polskiego i kolonizowanie kraju przez Niemców, którzy osiedlani byli na o wiele lepszych prawach i mieli dobre warunki do rozwoju ekonomicznego ${ }^{19}$.

Jarochowski i Zimmermann w Poznaniu czuli ciężar niemieckiego panowania i germanizacji, łatwiej jednak było chwalić Fryderyka II Michałowi Bobrzyńskiemu w Galicji czy w Warszawie Tadeuszowi Korzonowi, który pod niebiosa wynosił jego działalność cywilizacyjna i gospodarcza. Wady oczywiście także odpowiednio komentował ${ }^{20}$. Szymon Askenazy nawoływał, żeby „nie żalić się” i „nie kwękać” na Fryderyka, a prowadzić zimną analizę źródeł, ale na próżno. Sam doceniał mądrość pruskiego władcy, jego inteligencję i pracowitość, zarazem jednak dostrzegał, znowu wyłącznie z perspektywy polskiej, podstępność, chciwość, nierespektowanie traktatów. Jak wskazuje Andrzej Kamieński historiografia polska zajmowała się prawie wyłącznie stosunkiem Fryderyka do Polski, co powodowało deformację oceny jego działalności ${ }^{21}$. Zauważył to już sto lat temu Szymon Askenazy, podkreślając, że historia Prus jest dla Polski niezmiernie ważna i jest to zadanie pierwszorzędne ${ }^{22}$.

Nietrudno też o uogólnienie, że polscy historycy do dzisiaj nazbyt często oczekują moralności tam, gdzie jej oczekiwać nie należy, czyli w dawnej polityce zagranicznej i dyplomacji, a zupełnie nie zwracają uwagi na te obszary, gdzie moralność jest jak najbardziej na miejscu, czyli w stosunkach społecznych i wewnątrzkrajowych. Humanitarne reformy Fryderyka II na tym obszarze zostały w Polsce uznane za podstępne.

Ostatecznie nie ma zbyt wielu historyków, którzy analizują trzeźwo pozytywne aspekty dokonanych przemian. Jako jeden z niewielu, Jerzy Jedlicki w 1988 r. pisał o niewattpliwej przewadze cywilizacyjnej Prusaków w 1793 r.: „wszelako możliwości polskiego uczenia się od Niemców zostały z miejsca przekreślone przez pogardliwą arogancję nowych okupantów i ich nieskrywane zapędy germanizacyjne, które wytworzyły

${ }^{18}$ K. Zimmermann, Fryderyk Wielki i jego kolonizacja rolna na ziemiach polskich, t. 1, Kraków 1915, s. V-VI, 75-112, 264-266.

${ }_{19}$ Tenże, Germanizacja Wielkopolski przez Polaków w drodze kolonizacji $w$ XVII i XVIII wieku, „Rok Polski”, t. 4, 1918, s. 209-225.

${ }^{20}$ T. Korzon, Wewnętrzne dzieje Polski za Stanisława Augusta (1764-1794), t. 2, Kraków-Warszawa 1897, s. 31.

${ }^{21}$ A. Kamieński, Fryderyk II..., s. 105; R. Gherke, dz. cyt., s. 224-225.

${ }^{22}$ H. Labrenz, Zur neueren polnischen Einschatzung Friedrich des Großen: Eine Posener und eine Thorner Schule?, w: Fridericianische Miniaturen 1, red. J. Zeichmann, Bremen 1988, s. 193-206. 
stan zagrożenia kultury narodowej - ostatniego schronienia polskości”23. Też to przesada, wielu, jak Feliks Łubieński się uczyło, a w Księstwie Warszawskim zachowano całą organizację pruska jako dobrą i sprawna.

Po 1989 r. osłabły też bardzo studia nad problematyką społeczno-ekonomiczna, zwłaszcza dotycząca warstw niższych, co pogorszyło jeszcze sytuację, utrudniając dostrzeganie społeczno-gospodarczego kontekstu problematyki pruskiej. Janusz Tazbir pisał niegdyś, że książki opowiadające o nieustannym wzroście ucisku poddanych zalegają nieczytane na półkach księgarń ${ }^{24}$. Sytuacja pod tym względem zmieniła się radykalnie. W naszej „włościańskiej” historiografii wytworzyła się stopniowo luka. Sporo racji ma Nikodem Bończa Tomaszewski, gdy pisze: „Słabość historiografii wsi polskiej ma szersze kulturowe podłoże. Polskie środowiska akademickie, zdominowane od swoich dziewiętnastowiecznych początków przez inteligencję, traktują tematykę chłopską jako drugorzędna. Chłopi postrzegani są przede wszystkim ze wstydliwej dla Polaków perspektywy modernizacji, jako oznaka bądź źródło zacofania, które należałoby przezwyciężyć”"25. Włodzimierz Mędrzecki słusznie stwierdził, że „złotym okresem” badań nad chłopami były dziesięciolecia po roku 1956 do roku 1970. Już wówczas zaczęło się nasilenie zainteresowań warstwami posiadającymi i inteligencja ${ }^{26}$. Wypracowany w PRL-u jasny model interpretowania zacofanej Europy Wschodniej jako Europy pańszczyzny i wyzysku chłopów, stanowiących prawie cały naród (Małowist, Kula, Topolski) obecnie uległ rozmyciu w dystynkcje i kategoryzacje całkiem dowolne i przebiegające według chwilowych potrzeb politycznych ${ }^{27}$.

Jeżeli chodzi o ocenę Prus, typowa jest narracja interesującego przecież i piszącego ciekawie historyka Jarosława Czubatego. Przede wszystkim autor ów mówi rozlegle o upokorzeniach, zagrożeniach i klęskach, doznanych przez Rzeczpospolitą od Prus - np. Polacy pozbawieni zostali wpływu na sprawy polityczne i publiczne, tak jakby wcześniej poza elitą był on znaczący. Analizując zmiany w systemie prawnym

${ }^{23}$ J.Jedlicki,JakiejcywilizacjiPolacypotrzebuja. Studiazdziejówwiedzyiwyobraźni XIX w., Warszawa 1988, s. 39-41. Pozytywne oceny: R. Kowalczyk, Polityka gospodarcza i finansowa Księstwa Warszawskiego w latach 1807-1812, Łódź 2010, s. 16-41.

24 J. Tazbir, Kultura szlachecka w Polsce, Poznań 1998, s. 15.

${ }_{25}$ N.B. Tomaszewski, Polskojęzyczni chłopi? Podstawowe problemy nowoczesnej historii chłopów polskich, KH, t. 112, 2005, z. 2, s. 94-95.

${ }^{26}$ W. Mędrzecki, Przemiany warstwy chtopskiej $w$ XIX $i$ XX wieku, w: Metamorfozy społeczne. Badania nad dziejami społeczeństwa polskiego XIXi XX w., [t. 1], red. J. Żarnowski, Warszawa 1997, s. 112-114.

27 A. Sosnowska, dz. cyt., s. 276-282, 330-331. 
pisze o justycjariuszach $\mathrm{w}$ sądownictwie wiejskim, w ogóle nie wspominając, że sędziowie publiczni byli ogromnym postępem wobec tradycyjnego sądownictwa patrymonialnego, w szkolnictwie zauważa tylko germanizację, chociaż Prusy miały najnowocześniejszy system edukacyjny w Europie. Plusów prawie nie ma, natomiast minusy scharakteryzowane sa jako nadmiar narzucających nowe porządki rozporządzeń i edyktów, i tu znowu „niektóre” rozsądne w większości „absurdalnie drobiazgowe”, w czym autor powtarza XIX-wieczne opinie Władysława Smoleńskiego ${ }^{28}$. Nadmiar nazbyt szczegółowych, często z XX-wiecznej perspektywy niemądrych edyktów jest oczywiście prawda - Wolfgang Neugebauer pisze nawet o „literackim” charakterze państwa pruskiego, a podobnie było w Austrii Józefa II. Sa to jednak mniej ważne kwestie wobec istotnych przemian instytucjonalnych, świadomości i realnych reform ${ }^{29}$. To juz Wawrzyniec Surowiecki w czasach trudniejszych niż dzisiejsze w 1812 r. pisał bardzo pochlebnie o zaborcach: „Zaraz po pierwszym rozbiorze rządy oświeceńsze znając, że większa lub mniejsza pomyślność najliczniejszej klasy narodu ma główny wpływ na pomyślność całego kraju, miały sobie za pierwszy obowiązek zatrudnić się ułagodzeniem stanu i losu włościan w prowincjach oderwanych. Jak Austria, tak Prusy, nie chcąc na moment cierpieć nieograniczonej władzy panów nad nimi, wzięła ich pod opiekę rządowa, ulżyła ciężarów, wyznaczyła im forum sądowe, ułatwiła uwolnienie z poddaństwa, środki do nabywania własności i sposoby bronienia jej od cudzej chciwości" ${ }^{30}$.

O pruskich urzędnikach Czubaty pisze, że demonstrowali przekonanie o wyższości pruskich porządków nad polskim zacofaniem i bałaganem. W rzeczywistości to Polska szlachta demonstrowała dumnie Prusakom przekonanie o wyższości polskiego zacofania i bałaganu nad pruskim porządkiem. W ogóle zbyt wiele dobrego do powiedzenia o Prusakach nie ma - rządy pruskie są u niego „absurdalne”, „groteskowe”, „ocierające się o śmieszność”. Wspomina o „mrocznych stronach Wieku Świateł", jednak zapomina dodać coś o jasnych ${ }^{31}$. Autor ten nie

${ }^{28}$ J. Czubaty, Księstwo Warszawskie (1807-1815), Warszawa 2011, s. 17, 35, 40; tenże, Zasada „dwóch sumień”. Normy postepowania i granice kompromisu politycznego Polaków w sytuacjach wyboru (1795-1815), Warszawa 2005.

${ }^{29}$ W. Neugebauer, Das Bildungswesen in Preußen seit der Mitte des 17. Jahrhundert, w: Handbuch der Preußischen Geschichte, red. O. Büsch, Berlin-New York 1992, s. 605-798; Ch. Link, Zwischen Absolutismus und Revolution. Aufgeklärtes Denken über Recht und Staat in der Mitte des 18. Jahrhundert, w: Aufbruch aus dem Ancien régime. Beiträge zur Geschichte des 18. Jahrhunderts, Köln 1993, s. 196.

${ }^{30}$ W. Surowiecki, Moje lekcje statystyki dawane w 1812/1813, w: tenże, Wybór pism, Warszawa 1957, s. 446-447.

31 J. Czubaty, Księstwo Warszawskie ..., s. 36-39. 
zauważył wcale, że na ziemiach polskich wraz z Prusakami pojawił się jako zjawisko generalne, nowoczesny typ państwa i szeregu instytucji do których należała przyszłość i że groteskowy i anachroniczny był nie pruski etatyzm, ale sarmacki liberalizm. Nie zauważa w ogóle, że Księstwo Warszawskie w znacznym stopniu zachowało rozwiązania pruskie, które Polacy chwalili, a wzory francuskie zostały wprowadzone w zakresie generaliów ${ }^{32}$.

W literaturze polskiej chętnie mówi się też krytycznie o działaniach władz mających na celu ,integrację" ziem polskich z pruskimi. Pruska historia i jej bohaterowie, postacie - jak Fryderyk II - ulegały swoistej diabolizacji i wręcz tabloidyzacji na potrzeby propagandy i wpisania w teleologiczny ciag, rzekomo logicznie wiodacy od Lutra przez Bismarcka i Hindenburga do zbrodniarza Adolfa Hitlera. „Podczepienie" całej niemieckiej historii pod Hitlera zaczęło się w propagandzie alianckiej już w czasie wojny i było jednym z motywów likwidacji Prus w 1947 r. Warto zaznaczyć, że nie był to jakiś komunistyczny wymysł, ale nawet polski Kościół katolicki nie unikną tych powszechnych wówczas asocjacji - w liście biskupów z 1965 r. robi się paralelę od Albrechta Hohenzollerna, przez Fryderyka II, Bismarcka do wodza III Rzeszy. Niemcom przypisywano szereg negatywnych cech charakterologicznych - jak zaborczość i agresywność oraz amoralność, wiodących do napaści na Polskę. Zdarzały się mocne akcenty pozytywne, jak w wypadku Michała Bobrzyńskiego, który wysoko oceniał reformy wewnętrzne Fryderyka II, ale nie one nadawały ton. Po II wojnie światowej pojawiły się nowe funkcje oceny Prus - legitymizacja PRL-u, przez ogromny sukces w II wojnie światowej i barwne, imponujące rozmachem, obrazy bitwy o Berlin, gdzie nazizm ukazywany był jako konsekwencja pruskiego militaryzmu. Więc nareszcie skuteczni i nareszcie owoce zwycięstwa w postaci własnego państwa. Ponadto negatywny obraz Prus miał stanowić przeciwwagę dla pozytywnego obrazu Rosji ${ }^{33}$.

Dopiero lata 70. przyniosły większe zniuansowanie obrazu Fryderyka II i Prus w Polsce, ukoronowane ukazaniem się książki Stanisława Salmonowicza, gdzie szereg jego reform prawa i wewnętrznych ocenionych zostało pozytywnie. Salmonowicz jako historyk prawa był też autorem dużego studium o Landrechcie ${ }^{34}$. Hanna Labrenz już

32 Tamże, s. 145-150; por. D. Łukasiewicz, Polacy i Prusacy..., s. 242-243.

${ }^{33}$ E. Dmitrów, Czarna legenda Prus, w: Prusy. Pamięć i dziedzictwo, red. B. Kerski, Szczecin 2002, s. 65-66.

${ }^{34}$ H.-J. Bömelburg, Friedrich II zwischen Deutschland und Polen. Ereignis- und Erinnerungsgeschichte, Stuttgart 2011, s. 290-293, 308-309; H. Labrenz, Zur neueren polnischen..., s. 193-206; S. Salmonowicz, Prawo karne oświeconego absolutyzmu. 
w 1988 r. pisała, że historycy Polscy nie akceptują tez o tysiącletniej wojnie polsko-niemieckiej i kontynuacji antypolskiej polityki od Fryderyka II do Hitlera ${ }^{35}$.

Współcześnie zdaniem Hansa-Jürgena Bömelburga i Stanisława Salmonowicza, wyważone i nowoczesne ujęcie dziejów Prus prezentuje poznańska synteza dziejów Prus, której tom trzeci, obejmujacy lata 1806-1871, właśnie znalazł się w księgarniach ${ }^{36}$.

Ciągle jednak $\mathrm{w}$ historiografii dominuje obraz pełen mimowolnych nawet kalek myślowych. Nawet znakomity przecież znawca XIX w. Andrzej Chwalba, rozumiejący świetnie złożoność procesu modernizacji, pisze stereotypowo o karnych i zdyscyplinowanych, zorganizowanych na wzór armii urzędnikach pruskich ${ }^{37}$. Tymczasem ten powszechny w Polsce, koszarowy i ewidentnie infantylny obraz pruskiej biurokracji jest zupełnie nieprawdziwy. W rzeczywistości pruska warstwa inteligencji (Bildungsbürgertum) nie była wprawdzie politycznie rewolucyjna, jednak była znakomicie wykształcona, postępowa i nowoczesna, wywodziła się bardzo często z mieszczaństwa, świadcząc o możliwości awansu cywilizacyjnego w Prusach. Na przełomie XVIII i XIX w. na 432 radców 295 było pochodzenia mieszczańskiego. Głównym kryterium awansu stało się wykształcenie - prawie wszyscy radcy musieli mieć wykształcenie uniwersyteckie. Podobnie nie urodzenie, ale zasługi były teraz kryterium awansu zawodowego, który znajdował odzwierciedlenie w wysokości pensji. Przyznać należy jednak, że wobec bardzo niskich pensji na początku kariery urzędniczej zamożność rodziców odgrywała nadal ważną rolę. Przypomnijmy, że w Polsce urzędnicy pracowali bez wynagrodzenia (do 1772 r.) i szlachta uważała to za słuszne, ale już w Księstwie Warszawskim podtrzymano nowoczesne pruskie regulacje, co dla wielu było gorszace. Jak pisał Józef Wybicki, „Dla dobrego Polaka słowo pensja jest bardzo nieprzyjemne”38. Mieszczaństwo pruskie bywało często postępowe i reformatorskie - trwała tu, przekładająca się na rozwiązania praktyczne, burzliwa dyskusja

Z dziejów kodyfikacji karnych przełomu XVIII i XIX w., Torun 1966; E. Dmitrów, Niemcy i okupacja hitlerowska w oczach Polaków. Poglady i opinie z lat 1945-1948, Warszawa 1987; F. Golczewski, Das Deutschlandbild der Polen 1918-1939. Eine Untersuchung der Historiographie und der Publizistik, Düsseldorf 1974, s. 64-102; P. Żbikowski, W monarchii pruskiej. „Gazeta Warszawska”1796-1806, Lublin 2013, s. 16.

${ }_{35}$ H. Labrenz, Zur neueren polnischen..., s. 193.

${ }^{36}$ H.-J. Bömelburg, dz. cyt., s. 328; S. Salmonowicz, O klasycznej monarchii pruskiej z lat 1701-1806, „Czasy Nowożytne”, t. 24, 2011, s. 233-247.

${ }^{37}$ A. Chwalba, Historia Polski 1795-1918, Kraków 2000, s. 176.

38 J. Wybicki, Pamiętniki Józefa Wybickiego, t. 1, Poznań 1840, s. 114. 
o potrzebie upowszechniania edukacji wśród ludu, zniesieniu poddaństwa, budowy dróg, modernizacji poczty, rolnictwa, czy to przez meliorację pól, stosowanie płodozmianu, zachęcanie do nawożenia, rozwijanie hodowli bydła, gromadzenie nawozu (jeszcze nie było zbawiennych nawozów sztucznych), propagowanie koniczyny, ziemniaka, hodowli owiec, poprawę rasy bydła i koni, wprowadzenie nowoczesnej hipoteki majątków ziemskich i kredytów hipotecznych, przeciwpożarowych kas ubezpieczeniowych, emancypacji kobiet, zniesienie poddaństwa, tortur, prześladowań czarownic, potrzebie zmian obyczajowych w rodzinie i seksualności, o jakiej w Polsce w tym czasie w ogóle nie mogło być mowy. Kiedy mówi się o dążeniach emancypacyjnych kobiet w Europie tego czasu, zwykle wspomina się wystapienia Francuzki Olimpii de Gouges z czasów rewolucji francuskiej i Angielki Mary Wollstonecraft z 1792 r., tymczasem pruski biurokrata i tajny radca, którego ojciec był wiejskim nauczycielem, prezydent Królewca Theodor Gottlieb Hippel już w 1792 r. opublikował rozprawę Über die bürgerliche Verbesserung der Weiber, w której opowiadał się za pełnymi prawami edukacyjnymi i politycznymi dla kobiet, dając świadectwo często postępowym poglądom pruskiego wykształconego mieszczaństwa. Hippel uważał, że zmiana sposobu wychowania i edukacji kobiet oraz konwenansów spowoduje, że kobiety staną się równe mężczyznom pod względem wykształcenia i odpowiedzialności ${ }^{39}$. O tym silnym duchu reformatorskim wśród urzędników pruskich, który ułatwił reformy po 1806 r. już dawno temu pisał Otto Hintze, a obecnie Rolf Straubel ${ }^{40}$. Porównując Polskę i Prusy warto zauważyć, że elitarnej i oligarchicznej oraz klientelnej demokracji szlacheckiej absolutystyczne Prusy przeciwstawiały wolności cywilne, w Polsce doceniane np. przez Stanisława Staszica, zwiększoną równość wobec prawa. W myśli ideologa Prus Christiana Wolffa (1679-1754) pojawiały się pierwsze promyki chrześcijańskiego państwa opiekuńczego, kiedy mówił on o konieczności sprawiedliwej płacy, uregulowania czasu pracy, ludzkich warunkach pracy i życia, trosce o publiczne szkolnictwo, opiekę lekarska, mieszkania. Droga do

${ }^{39}$ R. Straubel, Beamte und Personalpolitik im altpreußischen Staat. Soziale Rekrutierung, Karriereverläufe, Entscheidungsprozesse, Potsdam 1998, s. 26, 48; D. Łukasiewicz, Polacy i Prusacy..., s. 235-236, 245; G.A. Craig, Über die Deutschen, München 1991, s. 170-171; M. Maurer, Die Biographie des Bürgers. Lebensformen und Denkweisen in der formativen Phase des deutschen Bürgertums (1680-1815), Göttingen 1996.

${ }^{40}$ O. Hintze, Preußische Revormbestrebungen vor 1806, w: Regierung und Verwaltung. Gesammelte Abhandlungen zur Staats-, Rechts- und Sozialgeschichte Preussens, Göttingen 1976; R. Straubel, dz. cyt. s. 505-529. 
realizacji tego programu była jeszcze bardzo odległa - brakowało na to środków i instrumentów technicznych. Landrecht wskazywał „dobro wspólne" (od Justusa Lipsiusa) jako cel istnienia państwa ${ }^{41}$. Jak już jednak twierdził Thomas Hobbes w Lewiatanie z $1651 \mathrm{r} .^{42}$, państwo to proces przechodzenia od dzikiej walki każdego z każdym do zorganizowanego społeczeństwa, gdzie ludzie współpracują ze soba, aby osiagać lepsze efekty niż dla przetrwania zabijając się nawzajem. Jak czytamy, ludzie powołali państwo jako ograniczenie swojej wolności, dla „zachowania własnej osoby” i „bardziej szczęśliwego życia”. Przemoc państwa jest konieczna, aby dopilnować realizacji dobra, które dla Thomasa Hobbesa stanowi: „sprawiedliwość, słuszność, skromność, miłosierdzie, czynienie innym tego, co byśmy chcieli, aby nam czyniono [...]. Ugody bez miecza sa tylko słowami i nie maja mocy, by dać człowiekowi bezpieczeństwo". Jeszcze Arystoteles w Polityce pisał, że celem człowieka jest życie w państwie, a rodzina i państwo sa tworem istot, które rozróżniają dobro od zła i mają poczucie sprawiedliwości i niesprawiedliwości ${ }^{43}$.

W stuleciu XVIII było to przecież państwo absolutystyczne, a więc obowiązywał nadal pogląd, że jednostka jest „niepełnoletnia” i wymaga nadzoru, aby nie działała wbrew własnemu dobru i obiecywano, że gdy tylko lud oświecony edukacją dojrzeje, otrzyma pełną wolnośćc ${ }^{44}$. Już we fryderycjańskiej ordynacji Samuela von Cocceji z 1748 r., a potem w Landrechcie z 1794 r. mówi się o „równości wobec prawa”, co wprawdzie było dopiero pierwszym krokiem we właściwą stronę ${ }^{45}$. Jeżeli coś było w Prusach problemem, to nie biurokracja - liczebnie niezwykle ograniczona, nawet jeszcze przez całe XIX stulecie - ale militaryzacja państwa, polegająca na zbyt dużej roli junkrów - oficerów. Jak podaje Emil Carsten w pruskim korpusie oficerskim w 1806 r. na 7-8 tys. osób było tylko 695 mieszczan. I tu jednak należy rozumieć relatywność tego stwierdzenia - policja pruska była ograniczona jeszcze w XIX w. do dwóch żandarmów na powiat ${ }^{46}$.

${ }^{41}$ Ch. Link, dz. cyt., s. 192; A. Schwennicke, Die Entstehung der Einleitung des Preußischen Allgemeinen Landrechts von 1794, Frankfurt a. M. 1993, s. 304-305.

${ }^{42}$ T. Hobbes, Lewiatan, czyli materia, forma $i$ władza państwa kościelnego $i$ świeckiego, Warszawa 2005, s. 253-254.

${ }^{43}$ Arystoteles, Polityka, Warszawa 2002, s. 17-18.

${ }^{44}$ F. Hartung, Der aufgeklärte Absolutismus, w: tenże, Staatsbildende Kräfte der Neuzeit, Berlin 1961, s. 158.

45 A. Schwennicke, dz. cyt., s. 218-219.

${ }^{46}$ E. Carsten, Geschichte der preußischen Junker, Frankfurt a. M. 1988, s. 44. 


\section{Apologia Sarmatyzmu}

Na historyków miały oczywiście ogromny wpływ przemiany lat 80.90. Wpływ kontekstu politycznego i cywilizacyjnego na badania historyczne był oczywisty i dla Jerzego Topolskiego, jest też jasno widoczny w różnych badaniach socjologicznych, przede wszystkim związanych $\mathrm{z}$ socjologia wiedzy i filozofia nauki, ale też $\mathrm{w}$ historii historiografii ${ }^{47}$. Od lat 80., i to już przed upadkiem PRL-u, także w reformatorskich środowiskach PZPR-u na tradycyjne przesłanki niechęci wobec Prus nakładała się modna ówcześnie, bardzo żenująca wrogość wobec oświecenia, które zaczęto rozumieć w sposób płaski i jednostronny oraz zdeformowany jako źródło i poprzednika komunizmu, chętnie sięgając do przykładu jakobinów i kwestii laicyzacji, co je dyskredytowało całkowicie. Pojawiły się u nas książki ukazujące oczywiste niezrozumienie dla istoty przemian cywilizacyjnych i kulturowych, jak obecnie praca Piotra Żbikowskiego o recepcji kultury Zachodu w Polsce przełomu XVIII i XIX w. Autor poświęca tu cały rozdział cenzurze, co jeszcze ujdzie, ale kolejny filozofii i historiozofii, nauce, odkryciom geograficznym, literaturze, teatrowi, tak jakby to były zagadnienia kluczowe dla rozwoju cywilizacyjnego. Jeden tylko rozdział jest przeznaczony na problemy obyczajowe i społeczne, ujęte w sposób bardzo przypadkowy, za to kompletnie nic nie ma o problemach rozwoju cywilizacyjnego. Mówi się tu jednak tylko o Francji i rewolucyjnych nowinkach, o wpływie Prus właściwie ani słowa. Podobnie często całe zjawisko oświecenia interpretuje się $\mathrm{w}$ kategoriach problemu z zakresu literatury i sztuki ${ }^{48}$. W mniejszym stopniu ma miejsce interpretowanie wszystkich działań rozbiorców jako wymierzonych w polskość, germanizujących i mających na celu wyniszczenie Polaków ${ }^{49}$.

Ponadto znudziły się i zbanalizowały tradycyjne oświeceniowe interpretacje i uzasadnione przecież moralnie emocje zerwania $\mathrm{z}$ „mrokami średniowiecza" (przedwojenny ludowiec Józef Putek został nieładnie zdyskredytowany jako propagandowa agitka), z dzikością i barbarzyństwem w naszych czasach wyczerpały się i zapomniano, na czym polega dystynkcja między tradycją a nowoczesnością. Trzeba więc to niestety powtórzyć, bo to kwestia kluczowa przy ocenie rządów pruskich

${ }^{47}$ J. Topolski, Teoria wiedzy historycznej, Warszawa 1985; P.L. Berger, Th. Luckmann, Społeczne tworzenie rzeczywistości, Warszawa 1983.

${ }^{48}$ P. Żbikowski, Mit Zachodu po rozbiorach, Kraków 2011, s. 87-115.

${ }^{49}$ W. Kujawski, Polityka pruska wobec Kościoła katolickiego na ziemiach zabranych Polsce w końcu XVIII wieku, w: Kujawy Wschodnie i Ziemia Dobrzyńska w okresie przejścia pod zabór pruski w 1793 roku, red. S. Cackowski, Włocławek 1995, s. 35-63. 
w Polsce. Prądy oświeceniowe pojawiły się w Polsce już we wcześniejszych dziesięcioleciach wieku XVIII, mocniej w okresie stanisławowskim, jednak Prusy były nimi przeniknięte nieporównanie silniej, a więc rozbiory musiały oznaczać przeniesienie ich również na ziemie polskie. Odrzucenie barbarzyństwa oznacza ogromny zespół zjawisk powszechnie znanych, jako ledwie przykłady można wymienić wielka humanitaryzację prawa przez odrzucenie albo ograniczenie stosowania tortur, rezygnację z okrutnych kar, zaprzestanie prześladowania kobiet oskarżonych o czary etc. Wprawdzie jednym z nowych zjawisk była laicyzacja i sekularyzacja, ale zarazem oświecenie realizowało w rzeczywistości lepiej niż dotąd chrześcijańskie wartości i wyobrażenia na temat właściwych relacji międzyludzkich. Wraz z oświeceniem pojawiły się również zmodernizowane i unowocześnione prądy katolicyzmu i protestantyzmu. Wszystko to razem Immanuel Kant określił jako wyjście z dzieciństwa ludzkości, niepełnoletniość, osiagnięcie dojrzałości. Kant powiadał też, że człowiek musi się odważyć myśleć samodzielnie, bez obcego kierownictwa. Metafora światła oznaczała rozproszenie mroków ciemności. Gdańszczanin Daniel Chodowiecki na miedziorycie Aufklärung ukazywał oświecenie graficznie jako blask wschodzącego Słońca, rozpędzającego mroki otaczającego świata ${ }^{50}$. Zapaleni krytycy oświecenia powinni też pamiętać, że bardzo często oświecenie było robione przez ludzi Kościoła (Krasiński, Piramowicz, Wyrwicz, Kołłataj, Staszic, Konarski i inni), zwłaszcza już w Polsce, gdzie warstwa inteligencji była jeszcze bardzo słaba, warstwa urzędnicza rachityczna, rynek czytelniczy ograniczony, poglądy mocno konserwatywne. Silne były prądy oświeceniowe w szkolnictwie jezuickim ${ }^{51}$.

Pojawiły się bardzo nieadekwatne, niedotykające istoty rzeczy analizy oświecenia i prądów mu przeciwnych. Martyna Deszczyńska w niedawno opublikowanej monografii analizuje prądy antyoświeceniowe. Jako oświeceniowe definiuje zupełnie dowolnie i selektywnie rzeczywiście ważne pozbawienie władzy legitymacji religijnej (Baruch Spinoza), odrzucenie religii jako podstawy funkcjonowania prawa, szkolnictwa etc., racjonalizm odrzucający tradycję, np. nierówności stanowe, oraz ogólnikowo ujętą filozofię oświeceniowa. Warto zauważyć, że w Polsce w ogóle chętnie analizuje się idee i myśl, które moga powstawać w cywilizacji i barbarzyństwie, i gdziekolwiek, ale mało jest analiz

${ }^{50}$ I. Kant, Co to jest Oświecenie?, w: T. Kroński, Kant, Warszawa 1966, s. 164-173; J. Snopek, Oświecenie. Szkic do portretu epoki, Warszawa 1999, s. 8-10.

${ }_{51}$ M. Janowski, Narodziny inteligencji 1750-1831, Warszawa 2008, s. 56; J. Snopek, dz. cyt., s. 14-15. 
wdrożeń idei, może dlatego, że wdrażali głównie inni. Nie jest to przypadkowe, bo czasopismo „Wiek Oświecenia” podobnie poprzestaje głównie na przejawach tradycyjnie rozumianej kultury artystycznej ${ }^{52}$.

Znaczacym uwarunkowaniem dla obrazu Prus w Polsce był neoliberalizm. W III RP, a nawet wcześniej, w latach 80 . XX w. pojawiła się popularna neoliberalna wrogość do wszelkich instytucji publicznych i państwowych, które miały być rzekomo ze swej natury niereformowalne i niewydajne, ideologia TINA i mit trickle-down theory, szukanie rozwiazań wszelkich bolączek w prywatyzacji, a nie naprawie państwa, wrogość wobec ingerencji państwa w życie społeczne, gospodarcze i kulturowe $^{53}$. W 1989 r. ukazał się artykuł, a w 1992 r. książka Francisa Fukuyamy Koniec historii, której autor ogłosił, że porządek liberalny jest zwieńczeniem procesu historycznego i nic innego nam się już nie przydarzy. Fukuyama potępiał też jako niewydajne i blokujace rozwój nie tylko rządy totalitarne, ale i autorytarne. W kontekście pruskim zdecydowanie nie przyją się w Polsce kulturalizm, wyjaśniający religijnie rozwój cywilizacyjny (Samuel Huntington), bo oznaczało to akceptację dla tez weberowskich o roli protestantyzmu ${ }^{54}$. W naukach humanistycznych w ogóle przyjęła się konserwatywna wersja narracji modernizacyjnej, „tendencja ta objawiała się optymizmem rozwojowym, dzieleniem aktorów politycznych na reformatorów i oszołomów, a aktorów społecznych - na zdolnych do wzięcia spraw w swoje ręce oraz nieudaczników o wyuczonej bezradności. Towarzyszyło temu ograniczenie perspektywy porównawczej do krajów najbardziej rozwiniętych, milczące założenie o «europejskości» polskiego społeczeństwa i jego niektórych sąsiadów oraz skojarzenie zacofania ekonomicznego regionu wyłacznie z okresem państwowego socjalizmu" ${ }^{55}$. Interpretacje zawarte w historiografii PRL-u zostały potępione, mimo że poza pewnymi obszarami, szczególnie dotyczacymi dziejów wieku XX, reprezentowały one bardzo wysoki poziom badawczy, a w każdym razie zasługujacy na merytoryczna dyskusję. Rafał Stobiecki słusznie zwraca uwagę, że wielcy badacze w rodzaju Witolda Kuli mieli wpływ na twórczość najwybitniejszych przedstawicieli historiografii światowej, jak Immanuel Wallerstein, Eric Hobsbawm czy Fernand Braudel ${ }^{56}$. Przypomnieć trzeba wysoka pozycję Jerzego Topolskiego czy Mariana Małowista oraz wielu innych.

\footnotetext{
${ }^{52}$ M. Deszczyńska, Polskie kontroświecenie, Warszawa 2011, s. 7-9.

53 T. Kowalik, www. transformacja.pl, Warszawa 2009, s. 25-41.

54 A. Sosnowska, dz. cyt., s. 337-339.

55 Tamże, s. 13.

${ }^{56}$ R. Stobiecki, Historiografia PRL, Warszawa 2007, s. 228.
} 
Podobnie było z niezwykle modną w Polsce w latach 80. i początku 90. książka filozofa Karla Poppera Społeczeństwo otwarte $i$ jego wrogowie, która zawiera zdumiewająca arogancką tyradę na temat „pismaka” Hegla i państwa pruskiego i nie jest niczym więcej jak pełnym wyzwisk pamfletem $^{57}$. Oto zdaniem Poppera „bełkot”, „poniżanie rozumu, „idiotyczne mrzonki” albo „gryzmoły”, „patologiczna gonitwa myśli”, „niestrawność stylu”, „wtórność” i „brak talentu Hegla”, który był „płaskogłowy”, „mdły”, „nudny” i „nieuczony”, sprawiły, że Hegel mógł odnieść sukces tylko dzięki temu, że był oficjalnym filozofem dworu pruskiego ${ }^{58}$. Hegel, realizując interesy elit pruskich, wystapił rzekomo przeciwko ideom rewolucji francuskiej „wolności, równości i braterstwa”, a jego filozofia stanowiła przedsionek nazizmu. Grzech Hegla polega na tym, że darzy szacunkiem państwo, naród i historię, prowadzi rzekomo apologię prusactwa, a „ich teorią było, że państwo jest wszystkim, a jednostka niczym" ${ }^{59}$. Co jest nawet nie uproszczeniem, ale po prostu nieprawda. W czasach, kiedy w Polsce takie pomysły wywoływały zgrozę, władca Prus tam gdzie mógł, a więc w majątkach państwowych, zniósł poddaństwo chłopów. Szlachta pruska opierała się temu podobnie jak polska. Zdaniem Poppera Hegel znosił wszelka jednostkową moralność i sumienie, a jedynym bytem decydującym o wszystkim stawało się państwo, rządzone przez króla pruskiego. Przy tym myślenie Hegla wynikało jedynie z przesłanek koniunkturalnych, konformizmu i chęci podlizania się władcy Prus, który płacił mu pensję. Tymczasem w rzeczywistości Popperowi nie chciało się nawet na tyle zapoznać z historią Prus, żeby zorientować się, że Hegel był nadwornym filozofem nie Fryderyka Wilhelma II, ale III i to późno, bo od 1818 r. ${ }^{60}$ Czytamy stwierdzenia kompletnie fałszywe i groteskowe, że prawa w Prusach nie było i jedynym suwerenem dyktującym poddanym, co mają robić, był król i że Hegel propagował nierówność wobec prawa. O wprowadzajacym w 1794 r. równość wobec prawa Powszechnym Pruskim Prawie Krajowym Popper z cała pewnością nie słyszał. „Duch Świata” służył po to głównie, aby wcielić się w historię Prus, które to państwo stało się dzięki temu przejawem doskonałości ${ }^{61}$. Co jest tu ważne, to utwierdzanie Polaków w z dawna zastanym pogladzie, że instytucja państwa jest nie pomoca słabszym, ale niebezpieczeństwem odwiecznym absolutum dominium, kosztowną zawalidroga

\footnotetext{
${ }^{57}$ K. Popper, Społeczeństwo otwarte i jego wrogowie, t. 2, Warszawa 2010.

58 Tamże, s. 46-47, 49-50.

59 Tamże, s. 48-49.

60 Tamże, s. 52-53.

61 Tamże, s. 64-66.
} 
w rozwoju ekonomicznym. W manifestach ideowych tych czasów, również u wspomnianego Poppera, nie mówi się prawie o rozwoju państwa opiekuńczego i jego problemach, wspomina się tylko czasem enigmatycznie, że opóźniało wzrost gospodarczy i było niewydajne, prowadząc, jak to z hipokryzją ujmowano, do „zubożenia” ludności. Nie mówi się o narastających na Zachodzie nierównościach od lat 70. XX w. Jest tylko wygodne przeciwstawienie scentralizowanej nieefektywnej gospodarki socjalistycznej i efektywnej liberalnej, występującej jakoby tylko w jednym neoliberalnym modelu. Mówi się o tryumfie kapitalizmu w bloku wschodnim po roku 1989, a nie o całkowitym zrujnowaniu i rozkładzie i zapaści gospodarki Rosji przez reformy Jeffreya Sachsa. Mechaniczne podnoszenie poziomu edukacji, zalecane przez Fukuyamę, miało podnosić poziom gospodarczy, co okazało się nie takie proste - edukacja nie jest bynajmniej czynnikiem wystarczajacym ${ }^{62}$.

Przede wszystkim jednak powstały liczne prace rehabilitujace nie tylko Sarmatyzm, ale nawet, co już kompletnie niezrozumiałe, najbardziej wsteczny okres saski. Wojciech Kriegseisen zauważył trafnie, że negatywny obraz Sarmaty uformował się już w epoce oświecenia i był to wizerunek „nieokrzesanego jegomościa mówiącego strasznym językiem pełnym makaronizmów, upijającego się do nieprzytomności na sejmikach i rąbiącego się tam szablą z sąsiadami” ${ }^{63}$. Teraz próbowano zanegować największe oczywistości. Podobnie autorka analizy systemu sarmackiej „złotej wolności” powiada, że to okres oświecenia przyniósł gwałtowne ataki ze strony swoich i obcych na szlachecką wolność jako przyczynę anarchii i upadku państwa ${ }^{64}$. Ulryk Werdum już w 1670 r. pisał o „nieokiełznanej wolności” szlachty. We francuskiej encyklopedii Rzeczpospolita jest chorym człowiekiem Europy, symbolizowanym przez kołtuna polskiego (plica polonica) oraz uosobieniem anarchii i warcholstwa ${ }^{65}$. W rezultacie standardowy dla PRL-u skrót oceny epoki saskiej dał Jarema Maciszewski, który napisał: „Rozpoczał się najczarniejszy okres w dziejach dawnej Rzeczypospolitej”. Była to prawda, i to bardzo banalna ${ }^{66}$. Dosyć podobna dla PRL-u i dla

${ }^{62}$ F. Fukuyama, Koniec historii, Poznań 1996; J. Stiglitz, Globalizacja, Warszawa 2007.

${ }^{63}$ W. Kriegseisen, Sejmiki Rzeczypospolitej szlacheckiej $w$ XVII $i$ XVIII wieku, Warszawa 1991, s. 204.

${ }^{64}$ M. Forycki,Anarchiapolskaw myśli Oświecenia.FrancuskiobrazRzeczypospolitej szlacheckiej u progu czasów stanisławowskich, Poznań 2004; A. Grześkowiak-Krwawicz, Regina Libertas. Wolność w polskiej myśli politycznej XVIII wieku, Gdańsk 2006, s. 5.

${ }_{65}$ U. Werdum, Dziennik Podróży 1670-1672, Wilanów 2012, s. 72-73.

${ }^{66}$ J. Maciszewski, Szlachta polska i jej państwo, Warszawa 1969, s. 197. 
konserwatystów krakowskich, jak Michał Bobrzyński: „Historia pierwszej połowy XVIII w. to jeden obraz grubego materializmu pozbawiony światła [...] Dziwna ciemnota ogarnęła umysły polskie niegdyś tak garnące się do światła, tak chciwe, gorączkowo przyswajające sobie wyniki powszechnego postępu i wiedzy [...] Jezuici polscy stoczyli się z całym narodem w przepaść upadku [...] Cofnęło się też społeczeństwo nasze szlacheckie w oświacie swojej daleko poza inne europejskie narody, za któremi niegdyś tak odważnie i śmiało kroczyło"67. Jak zwraca uwagę niemiecki historyk, dla konserwatystów krakowskich ważną rolę odgrywało przeciwstawienie szlacheckiej anarchii pruskiemu porządkowi, co nadawało jej etatystyczne piętno i ostatecznie częściowo przejmowali ocenę Rzeczypospolitej od szkoły pruskiej ${ }^{68}$. Nie inaczej pisali o nas późniejsi historycy niemieccy. Gottfried Schramm wskazał jasno na narastajacy w XVII w. anachronizm gospodarki folwarczno-pańszczyźnianej, zapaść gospodarczą miast, coraz większy dystans między Rzeczpospolita a Prusami w rozwoju instytucji państwowych ${ }^{69}$.

Nowa historiografia chciała wystapić przeciwko tym oświeceniowym „stereotypom”, bo pojęcie stereotypu stało się akurat modne i wszystkie nieprzyjemne prawdy i niemiłe wzory kulturowe nazywano stereotypami uprzedzeniowymi, kliszami i kalkami językowymi. Zastosowano bardzo nieelegancki, kłamliwy i niedorzeczny zabieg przypisania wszelkiej krytyki Sarmatyzmu PRL-owi. Ostatnio pisał o tym Krzysztof Koehler. Twierdzi on, że krytyki wyzysku i ucisku chłopów, czyli w nowej nomenklaturze „wykluczenia”, pochodza z lat 40.-50. XX w. i połączone były z fizyczną eliminacją szlachty. Otóż, jak twierdzi Koehler, kultura szlachecka cechowała się przewaga czynnika duchowego nad materialnym; kultem wolności, obywatelskości, patriotyzmu, autorytetów i wzorów. Obecne nieśmiałe krytyki Sarmatyzmu uważane tu sa za właśnie występowanie przeciwko duchowości Sarmatyzmu. Koehler kwestię sytuacji prawie całego narodu, czyli chłopów, traktuje jako drugorzędna i nie kojarzy wcale negatywnie z zamiłowaniem Sarmatów do „wolności”. Określanie cech Sarmatyzmu jako „obskurantyzmu” uważa za przejaw „kompleksów” postkolonialnych i poczucia niższości, ale też atrofii i bezwładu. Krytykuje naśladowanie obcych wzorów i niedocenianie własnych, zapominając, że poczynając od wprowadzenia chrześcijaństwa, prawa magdeburskiego, od kolonizacji

${ }_{67}$ M. Bobrzyński, Dzieje Polski w zarysie, t. 2, Kraków 1890, s. 275-277.

${ }^{68}$ R. Gherke, dz. cyt., s. 208-209.

${ }^{69}$ G. Schramm, Szlachta i państwo na przykładzie Brandenburgii i Rzeczpospolitej Obojga Narodów w XVII wieku, w: Polska w dziejach Europy Środkowej. Studia, Poznań 2010, s. 178-181. 
niemieckiej w średniowieczu, potem Karoliny etc., dzieje Polski polegały w znacznym stopniu na recepcji i asymilacji po swojemu rozwiązań cywilizacyjnych Zachodu ${ }^{70}$.

Historyk krakowski Mariusz Markowski pisał na przykład w kluczowym podręczniku uniwersyteckim: „Czasy saskie były długo określeniem o charakterze pejoratywnym, panowało powszechne przekonanie, że jest to okres upadku Rzeczypospolitej Obojga Narodów, anarchii i utraty suwerenności" ${ }^{\prime \prime}$. W innym miejscu za dobra monetę bierze powiedzenie „za króla Sasa jedz pij i popuszczaj pasa”, dotyczące przecież tylko elit, podczas gdy w tym czasie śruba pańszczyźniana była cały czas dokręcana. Autor wykazuje się jednak empatia tylko wobec możnych, klasy uciskającej, broniąc jej przy każdej okazji, poczynając od stwierdzenia, że relacja między szlachtą a poddanymi nie miała charakteru despotycznego. Symptomatyczne, że w syntezie, gdzie ledwie sześć stron na 750 poświęca się prawie całemu narodowi, czyli chłopom, Markiewicz znajduje miejsce na wywód, że nie chłopi uciekali od szlachty, ale to szlachta organizowała ucieczki chłopów, bo każde ręce do pracy były cenne, więc bardzo o nie dbano i chłopi byli przez szlachtę nieledwie pieszczeni, jak pisze, poddaństwo nie było dla chłopów ,jedynie" uciążliwe, ale miało też zalety. Pisze, że sytuacja ekonomiczna chłopów jest „trudna do określenia”, „uogólnienia są zawodne”, więc nie uogólnia i pozostawia czytelnika w słodkiej niewiedzy, czy sytuacja materialna chłopa różniła się czymś od sytuacji magnata, czy też znowu było różnie. Stwierdza natomiast, że w cywilizacji rolniczej chłopi wszędzie, nie tylko w Rzeczypospolitej, ciężko pracowali i żyli na granicy ubóstwa. Trudno się zorientować, czy to w pełni usprawiedliwia nieróbstwo i opływanie w dostatki naszej szlachty ${ }^{72}$. W drugiej podstawowej syntezie historii Polski nowożytnej wyborna znawczyni tematu Urszula Augustyniak na 1000 stron tekstu chłopom poświęca cztery, dokładnie tyle, ile Żydom. Jak pisze ta autorka: „Obrazy nędzy i ucisku chłopów w literaturze były uogólniane (np. u Stanisława Staszica). W rzeczywistości brutalna eksploatacja poddanych była z punktu widzenia właścicieli dóbr nieopłacalna"73. Jest to logika dosyć częsta, chociaż zdumiewająca, bo można ją zastosować - i bywa zresztą stosowana - do każdej epoki i do każdej relacji pracodawcy i pracownika, przy czym

${ }^{70}$ K. Koehler, Cywilizacyjna energia Sarmatów, „Rzeczpospolita”, 9-11 XI 2013.

${ }^{71}$ M. Markiewicz, Czasy saskie i Saksonia, w: Między wschodem a zachodem. Etniczne, kulturowe $i$ religijne pogranicza Rzeczypospolitej $w$ XVI-XVIII wieku, red. K. Mikulski, A. Zielińska-Nowicka, Toruń 2006, s. 5.

${ }^{72}$ M. Markiewicz, Historia Polski 1492-1795, Kraków 2004, s. 650, 162-167.

${ }^{73}$ U. Augustyniak, Historia Polski 1572-1795, Warszawa 2008, s. 280-284. 
okaże się, że niewolnictwo Murzynów było nieszkodliwe ${ }^{74}$, a kapitalizm industrialny może nie był, ale powinien być sielanką dla robotników, zaś powstanie związków zawodowych było szkodliwą fanaberia. Przyczyny wyzysku są zróżnicowane, znane i mogą być dyskutowane. $\mathrm{Z}$ jednej strony kulturowe przekonania, które omawiam, z drugiej - chęć wzbogacenia się, z trzeciej - względy jednostkowe, powodujące, że jedni byli łagodniejsi od innych. Były też znane przyczyny łagodzące wyzysk, jak wartości chrześcijańskie nakazujące ludzkie traktowanie poddanych, miłość i miłosierdzie. Wiadomo przecież, że w różnych kulturach mniej i bardziej preferowane sa różne wartości, relacje sa bardziej egalitarne lub elitarne. Nie jest to jedynie kwestia indywidualnych upodobań.

Tak więc rozsądniejsi autorzy, jak Jerzy Topolski czy Maria Bogucka tłumaczyli wzrost eksploatacji chłopów spadającymi zyskami szlachty, która rekompensowała je sobie wzrostem robocizn - co odpowiada bardzo dramatycznej literaturze narracyjnej i nie prowadzi do wrażenia schizofrenii, gdzie współczesne polskie i cudzoziemskie opisy losu chłopskiego zupełnie odbiegają od konkluzji historyka ${ }^{75}$. Podobnie Jacek Staszewski o sytuacji chłopów w Polsce saskiej pisze, że był to „najczarniejszy okres poddaństwa”, bo odbudowa po wojnach następowała kosztem wzmożenia eksploatacji chłopa. Tę opinię podziela Józef Gierowski, tłumacząc, że depopulacja kraju powodowała, że szlachta zwiększała ilość obowiązków dla mniejszej liczby poddanych ${ }^{76}$. Edmund Kizik, który w najnowszym podręczniku uniwersyteckim Historii Polski do 1572 r. pisze o XVI w., kiedy sytuacja chłopów była jeszcze umiarkowanie znośna, o ogromnym pogorszeniu sytuacji chłopów wraz z nastaniem wtórnego poddaństwa. Słusznie zwraca uwagę, że nawet jeżeli chłopi nie byli traktowani masowo z okrucieństwem, to zdani byli na kaprysy, humory i zachcianki pana ${ }^{77}$.

${ }^{74}$ I. Berlin, Pokolenia $w$ niewoli. Historia niewolnictwa w Ameryce Pótnocnej, Warszawa 2010, s. 19-20.

${ }^{75}$ J. Topolski, Polska $w$ czasach nowożytnych 1501-1795, Poznań 1994, s. 563564, por. M. Bogucka, Między obyczajem a prawem. Kultura Sarmatyzmu w Polsce w XVI-XVIII wieku, Warszawa 2013, s. 44-45; taż, Kultura, naród, trwanie. Dzieje kultury polskiej od zarania do 1989 r., Warszawa 2008, s. 179; A. Sosnowska, dz. cyt., s. 276-282.

${ }^{76}$ J.A. Gierowski, The Polish-Lithuanian Commonwealth in the XVIII Century. From Anarchy to Well-Organised State, Kraków 1996, s. 105-106; J. Staszewski, 1696-1795, w: Polska na przestrzeni wieków, red. J. Tazbir, Warszawa 2006, s. 323; J. Gierowski, Blichtr i nędza. Spoteczeństwo polskie doby Augusta II, w: Na szlakach Rzeczypospolitej w nowożytnej Europie, Kraków 2008, s. 301-313.

77 E. Kizik, T. Jurek, Historia Polski do 1572 roku, Warszawa 2013, s. 616-619. 
Także Norman Davies bez wahania pisał o pogardzie i okrucieństwie szlachty wobec chłopów połaczonych w ideologii szlacheckiej z pełna hipokryzją z hasłem wzajemnej miłości. Wskazywał na jakiś dziwaczny kontrast miłości Jana Paska do własnej wydry i całkowitej nieczułości wobec cierpienia chłopów oraz na seksualne wykorzystywanie wiejskich dziewcząt przez panów. Pisarz barokowy Krzysztof Opaliński przypominał, że tak niegodziwie traktowani chłopi są przecież bliźnimi i ludźmi, podobnie jak szlachta ${ }^{78}$.

Dariusz Rolnik z kolei analizuje szlachecką literaturę pamiętnikarska, gdzie często występuje sielankowo-patriarchalny, bezkonfliktowy model stosunków między szlachtą a chłopami, będący podtrzymaniem autostereotypu. W wizerunkach tych pan jest dobry i sprawiedliwy, ale surowy. Chłop w tych relacjach żył dostatnio, bawił się i śpiewał. Widoczny jest jednak bardzo hierarchiczny, paternalistyczny i patriarchalny model relacji, gdzie chłopi traktują swojego pana z miłościa, jak rodzica, a następnie bardzo skapy i rzadki charakter wzmianek o chłopach, co wynika z uznania ich za mało ważny i ciekawy element życia pańskiego. Tłumy żebraków wynikać miały nie z biedy, ale z lenistwa chłopów. Jeden z pamiętnikarzy jako żart opisuje sytuację, w której chłop przenosił go na plecach przez błoto, aby się nie ubrudził, nazywając owego chłopa „wierzchowcem nowego rodzaju”. Poprawia się to nieco dopiero pod samo koniec wieku, kiedy zwracano uwagę na chłopów, częściej więcej było krytycyzmu wobec postępowania szlachty. Zauważano chętniej biedę w posiłku, mieszkaniu i stroju, ucisk i wyzysk, bicie oraz potrzebę poprawy w tym względzie. Szlachta polska podróżująca po krajach Zachodu dostrzegała duże różnice w zamożności poziomie życia chłopów tamtejszych i polskich. T. Węgierski pozwolił sobie nawet na uwagę, że Murzynowi było lepiej niż polskiemu chłopu ${ }^{79}$. Maria Bogucka cytuje Albrychta Radziwiłła, który już w 1649 r. mówił: „Nikt bardzie nie wyzyskiwał poddanych niż nasza Polska" ${ }^{80}$. W innym miejscu wszakże główny nacisk kładzie na klęski wojenne XVII i XVIII w., które doprowadziły do zubożenia chłopów, oceniając, moim zdaniem niesłusznie, że dawne pesymistyczne oceny sytuacji chłopów były przesadzone, chociaż przyznaje, że „chłopstwo przygniecione pańszczyzną" z trudem znajdowało nawet czas na pracę na własnym polu. Dramatyzm ówczesnego kryzysu - kanibalizm i samobójstwa wśród chłopów

${ }^{78}$ N. Davies, Boże Igrzysko. Historia Polski, Kraków 2003, s. 237-238.

79 D. Rolnik, Portret szlachty czasów stanisławowskich epoki kryzysu, odrodzenia i upadku Rzeczypospolitej w pamiętnikach polskich, Katowice 2009, s. 80-94.

${ }^{80}$ M. Bogucka, Między obyczajem a prawem..., s. 44. 
- przypomina także Józef Gierowski. Wskazuje, że po wojnach obciażenia chłopów niejednokrotnie tak wzrosły, że musieli brać parobków do wyrobienia dniówek pańszczyzny, na których ich nie było stać. Przecież wszakże Niemcy lżej wcale nie mieli i katastrofa wojny trzydziestoletniej czy siedmioletniej były może nawet bardziej tragiczne i pustoszące, a sytuacja chłopów potem jednak lepsza i pańszczyzny niższe. Ponadto autorka twierdzi przesadnie, że rzekomo w ostatnich latach miała miejsce jakaś fala badań nad sytuacją włościan, która zmieniła dawną błędną i pesymistyczną perspektywę. Cytowane przez nią prace dotyczą okresu sprzed drugiej połowy XVII w. i zajmują się inną tematyka albo pochodza jeszcze $\mathrm{z}$ lat 80 . XX w. ${ }^{81}$ Inne prace nie dotyczą relacji dworu i gromady. Na przykład Tomasz Wiślicz sądzi, że nie było częstego narzucania narzeczonej przez pana, ale zdarzało się nawet, że właściciel zaganiał siła do ołtarza swych poddanych dla zapełnienia pustego gospodarstwa, a częściej, że kawaler był już posunięty w latach (40 lat) i nakazano mu natychmiast się żenić. Jak wiadomo, nie było natomiast możliwe zawieranie małżeństwa poza majątkiem swego pana. Podobnie Michał Kopczyński sądzi, że narzucanie narzeczonej było rzadkim przypadkiem, inaczej niż w dawniejszej literaturze Witold Kula i Andrzej Woźniak ${ }^{82}$.

Poznański historyk Waldemar Łazuga stwierdził, że „anomalia rozwojowa” Polski była uniwersalistycznym oświeceniowym wymysłem, nieposiadającym realnego uzasadnienia i jedynie $\mathrm{z}$ oświeceniowego punktu widzenia sarmacka odrębność nie była cnota. Jak dalej stwierdza, PRL odrzucił tradycję Rzeczypospolitej sarmackiej, co uważa za przejaw „upolitycznienia” historii. „Biedna polska” historia wydana też została na łup „wulgarnego marksizmu”, gdzie była poniewierana jako „dom niewoli dla ludu, system krwiopijczego wyzysku chłopa i gniazdo rozbestwionej szlachty." Jak ubolewa autor, jeszcze w latach 60. przymiotnik ,szlachecki” miał pejoratywne znaczenie ${ }^{83}$. Robotniczy, egalitarny zryw solidarnościowy z socjalistycznymi postulatami gdańskimi

${ }^{81}$ Tamże, s. 61-63; J.A. Gierowski, The Polish-Lithuanian Commonwealth..., s. $105-108$.

${ }^{82}$ T. Wiślicz, Upodobanie. Matżeństwo i zwiazki nieformalne na wsi polskiej XVIIXVIII wieku, Wrocław 2012, s. 118-121; M. Kopczyński, Studia nad rodzina chłopska w Koronie w XVII-XVIII wieku, Warszawa 1998, s. 171-172; Dwór, plebania, rodzina chtopska, red. M. Ślusarska, Warszawa 1998; A. Woźniak, Kultura mazowieckiej wsi pańszczyźnianej końca XVIII i pocz. XIX w., Wrocław 1987; W. Kula, Teoria ekonomiczna ustroju feudalnego, Warszawa 1983 (rozdział „Dwór a rodzina chłopska”).

${ }^{83}$ W. Łazuga, Obraz pierwszej Rzeczypospolitej w historiografii polskiej XIX $i$ XX wieku, w: Między wschodem a zachodem..., s. 22, 26-27. 
był - zdaniem Waldemara Łazugi - podszyty „wolnościową ideologia szlachecka”" ${ }^{4}$. Z kolei Jerzy Dygdała w artykule U początków „Czarnej legendy” czasów saskich pisze bardzo zdecydowanie o „stereotypowym”, „negatywnym” obrazie czasów saskich i jego rehabilitacji przez współczesne badania, gdzie ja za bardzo powodów do tej rehabilitacji nie widzę $e^{85}$. Oczywiście, w czasach saskich nie brakowało ich sarmackich entuzjastów, ale nawet sam Dygdała stwierdza, że było to przejawem staroszlacheckiej mentalności i cytuje opinie krytyczne wobec sarmatyzmu, które bardzo rozpowszechniły się od czasów oświecenia ${ }^{86}$. Zarazem ów toruński badacz wysoko ocenił pruskie państwo oświeconego absolutyzmu XVIII w. i porównując je z Rzeczpospolita, zwraca zasadnie uwagę na wszystkie jej słabości i siłę Prus. Od znakomitej wykwalifikowanej biurokracji, często mieszczańskiego pochodzenia, przez świetnie zorganizowany pruski system fiskalny. Wskazuje, że z syntezy poznańskiej wynika wręcz wyższość oświeconego absolutyzmu pruskiego nad pozornie wolną Rzeczpospolita szlachecka ${ }^{87}$. Polemizując, mniejszą wagę przywiazywałbym do siły biurokracji, finansów, armii i państwa, a większą do bardziej uniwersalnych i porównywalnych z Polską elementów reform: społecznych, gospodarczych, prawa, sprawiedliwości, humanitaryzmu, obyczajów, szkolnictwa, nauki. Konstytucja 3 Maja porównana z częściowo jeszcze przecież feudalnym Powszechnym Pruskim Prawem Krajowym z 1794 r., jest bardzo anachroniczna. Mimo oczywistych mankamentów Prusy, zwłaszcza epoki Fryderyka II, ale nie tylko, wiodły tu wówczas prym w Europie, wyprzedzając inne kraje.

Józef Andrzej Gierowski krytykuje sarmacki hiperoptymizm: „Dzisiaj, kiedy wiele cech dawnych Polaków, tych z XVII i XVIII wieku okazało swoją nieoczekiwana żywotność, nie wolno podtrzymywać złudzeń i przeinaczeń odnoszących się do Rzeczypospolitej szlacheckiej"88. Natomiast autor ten słusznie zwraca uwagę, że należy mieć krytyczny stosunek do spychania winy za kryzys na Niemców - władców saskich ${ }^{89}$.

${ }^{84}$ Tamże, s. 27.

85 J. Dygdała, U początków „Czarnej legendy” czasów saskich, „Czasy Nowożytne”, t. 23,2010 , s. 63 .

${ }^{86}$ Tamże, s. 67-68.

87 J. Dygdała, Dzieje fryderycjańskich Prus $w$ XVIII w., czyli o wyższości absolutyzmu nad szlacheckq wolnościa, KH, t. 120, 2013, nr 3, s. 580, 588-591.

${ }_{88}$ J.A. Gierowski, Rozkład państwowości szlacheckiej w czasach saskich, w: Między Wschodem a Zachodem. Rzeczpospolita XVI-XVIII wiek, red. T. Chynczewska-Hennel i in., Warszawa 1993, s. 187-188.

89 J. Gierowski, Cienie i blaski czasów saskich, w: tenże, Na szlakach Rzeczypospolitej w nowożytnej Europie, red. A. Link-Lenczowski, Kraków 2008, s. 279-286. 
Jest też ciekawe, że z natury rzeczy nastawione modernizacyjnie syntezy dziejów Polski wieku XIX w. znacznie trzeźwiej traktują relacje szlachty z chłopami. Andrzej Chwalba wskazuje więc na ogromne pozytywne zmiany w zaborze pruskim, gdzie znikała dawna przepaść między stanami i wielki paternalizm ${ }^{90}$. Jeszcze dalej idzie Tadeusz Epstein, cytujący Świętochowskiego i używający jędrnego słownictwa typowo pozytywistycznej XIX-wiecznej jeszcze historiografii, by odmalować chłopską - tym razem galicyjską - nędzę i zacofanie. Przy ocenie szlachty jest jednak bardzo wstrzemięźliwy, nie przeczy feudalnej hierarchii, ale też raczej widzi pomoc dworu w sytuacjach kryzysowych dla umordowanych poddanych ${ }^{91}$.

Odnotować też trzeba pojawiające się w kontekście ocen Sarmatyzmu polskie ataki na absolutyzm oświecony, jak w wypadku Jacka Staszewskiego, Józefa Gierowskiego czy Anny Wolff-Powęskiej, niejednokrotnie całkowicie absurdalne. Tak jest np. ze stwierdzeniami w rodzaju (Staszewski), że kodyfikacje karne okresu oświecenia były niewiele albo wcale nie lepsze od wcześniejszej, przerażającej w swym okrucieństwie Karoliny z 1532 r. O rzeczywistym znaczeniu tych reform zupełnie inaczej pisze ostatnio Danuta Janicka: „wiek XVIII oznaczał dla europejskiego prawa karnego otwarcie nowego rozdziału w historii [...] dokonał się przełom, który oznaczał definitywne wyzwolenie z mentalności sięgającej jeszcze średniowiecza, z przesądów, ciemnoty" ${ }^{2}$. Podobnie historyk prawa Stanisław Salmonowicz obszernie analizuje oświeceniowy ruch humanitarny w państwach absolutystycznych (pojęcie humanitaryzmu rozwija się właśnie w okresie oświecenia), który wywołał rewolucję w prawie karnym ${ }^{93}$. Gdzie indziej stwierdza wręcz, że kodyfikacje oświeconego absolutyzmu są porównywalne z kodeksem Napoleona i otwierały drogę do budowania kapitalizmu ${ }^{94}$. Anna Wolff-Powęska pisze natomiast z dużą pewnościa siebie, że same pojęcia

90 A. Chwalba, dz. cyt., s. 78-84.

${ }^{91}$ T. Epstein, w: Historie Polski w XIX w., t. 1, Warszawa 2013, s. 70-71.

92 J. Staszewski, Absolutyzm oświecony a Polska XVIII stulecia, w: tenże, Jak Polskę przemienić $w$ kraj kwitnacy. Szkice i studia z czasów saskich, Olsztyn 1997, s. 203-211; D. Janicka, Nauka o winie i karze w dziejach klasycznej szkoty prawa karnego w Niemczech w I połowie XIX wieku, Toruń 1998, s. 21-22; J. Gierowski, Kilka uwag o absolutyzmie oświeconym w Europie Środkowej, w: tenże, Na szlakach Rzeczypospolitej..., s. 199-207; A. Wolff-Powęska, W kręgu „dobroczynnej rewolucji” oświeconego absolutyzmu, w: Myśl polityczna wieku Oświecenia, Poznań 1988, s. 64-86.

${ }_{93} \mathrm{~S}$. Salmonowicz, Z wieku Oświecenia. Studia z dziejów prawa i polityki XVIII wieku, Toruń 2001, s. 49-106.

94 S. Salmonowicz, Czy istniat Oświecony Absolutyzm w Europie XVIII wieku, w: Studia z historii ustroju i prawa, red. J. Olszewski, Poznań 2002, s. 340. 
absolutyzmu i oświecenia sa już tak ze sobą sprzeczne, że ich łączenie jest absurdalne. Autorka za najistotniejsze w oświeceniu uznaje pojęcia „wolności”, nie rozróżniając wolności „politycznej” i „cywilnej”, „religijnej”, którą absolutyzm oświecony w wielu razach bardzo poszerzał. Określenie „oświecony despota” miało być „bałamutne”, bo kończyło się na imprezowaniu króla z pisarzami i malarzami. Określenie „sługa państwa" było zdaniem Wolff-Powęskiej jedynie zręczną mistyfikacja. Mnie się zdaje, że raczej rewolucyjną i epokową wręcz zmiana, która desakralizowała państwo i zmieniała formę jego legitymizacji, razem z konserwatywna formą umowy społecznej (Hobbes). Skojarzeń na temat opieki władcy w Prusach nad włościanami i łagodniejszego wobec nich prawa oraz całkowitej samowoli w liberalnej demokracji szlacheckiej badaczka nie ma wcale. Jeżeli pozytywnie mówi o berlińskich elitach pruskich, to oczywiście z perspektywy filozofów, prawników „wolnych” zawodów, nie wspominając o nowoczesnej klasie urzędniczej, która jej się zapewne źle kojarzyła z biurokracją PRL- ${ }^{95}$. Zarówno w wypadku Staszewskiego, Wolff-Powęskiej, nieco mniej Gierowskiego, jak i Cegielskiego, w krytykach oświeconego absolutyzmu nie pojawiała się też wcale albo wystarczająco analiza jego podstawowych innowacji, oczywiście niejednokrotnie zapoczątkowanych już w XVII w. budowy nowoczesnych instytucji państwowych - szkolnictwa, nauki, służby zdrowia, policji, armii, socjalnych, podatków (początki równości), początków ubezpieczeń, laicyzacji państwa, tolerancji religijnej, ograniczenia cenzury światopoglądowej, unifikacji prawa, a też innych kwestii (moneta), reform prawa prowadzących do posunięcia sprawy równości wobec prawa nie tylko stanów, ale i płci, tworzenia się mieszczaństwa i inteligencji, ogromnej humanitaryzacji prawa karnego ${ }^{96}$. Na brak armii i nowoczesnej wykształconej biurokracji w Polsce zwróciła zwięźle uwagę Maria Bogucka, porównując Sarmatyzm do absolutyzmu i wskazując na szlachecki lęk przed absolutum dominium, blokujący wszelkie reformy ${ }^{97}$. Już w XIX w. Michał Bobrzyński zwracał uwagę na aspekty administracyjno-militarne: „Z początkiem XVIII wieku ujrzały już wszystkie państwa Europy wiekowe swoje usiłowania uwieńczone pomyślnym skutkiem. Wszędzie dokonała się ostateczna budowa władzy rządowej w nowy sposób pojętej. Wszędzie rząd skupił w swoim ręku nie tylko najwyższą władzę, ale zarazem wszystkie siły i zasoby narodu, rozległa administracja zapewniała mu szybkie i stanowcze

\footnotetext{
95 A. Wolff-Powęska, dz. cyt., s. 65-72.

96 S. Salmonowicz, Czy istniat Oświecony Absolutyzm..., s. 336.

${ }_{97}$ M. Bogucka, Kultura, naród, trwanie ..., s. 179.
} 
wykonywanie rozkazów a wyćwiczone stałe armie popierały jego politykę zagraniczna swoim zbrojnym naciskiem" "98. W tym samym czasie szlachta polska myślała, zdaniem historyka, następująco: „na co nam starać się o utrzymanie wielkiej siły zbrojnej i dawnej politycznej na zewnątrz przewagi, skoro to nas tak drogo kosztuje, abdykujmy lepiej ze wszelkiego głosu w Europie, dajmy naszym sasiadom gwarancję, że zawsze pozostaniemy bezsilni i słabi, a kiedy nie będziemy nikomu groźnymi, wszyscy nas zostawią w spokoju!"99.

Ogrom zasług absolutyzmu oświeconego jest tym bardziej widoczny, im bardziej u nas przemilczany albo pomniejszany. Kiedy mowa o sytuacji chłopów w Prusach - dla Jacka Staszewskiego - wszystkie reformy pruskie były niewystarczające, zbyt powierzchowne, wszystko robiono tam „jedynie”, a nic „aż. Tak jest w wypadku sytuacji chłopów, którzy zostali uwłaszczeni w Prusach ,jedynie” w majątkach państwowych, podczas gdy w Polsce „aż” pogadano o chłopach nieco na sejmach i wspomniano o nich zdawkowo i bez konsekwencji praktycznych w Konstytucji 3 Maja, nic kompletnie nie robiąc w ich sprawie. Może, że zakazano szlachcie mordować bezkarnie poddanych w 1768 r., co gdzie indziej zrobiono już dawno. Tak jest ze szkolnictwem pruskim, któremu Jacek Staszewski łaskawie pozwolił się rozwijać, bo można mu było przeciwstawić Komisję Edukacji Narodowej, wprawdzie jedynie w wyobrażeniach autora. Zamiast tego Jacek Staszewski mówi o niewielkim wpływie państwa XVIII-wiecznego na gospodarkę, co korzystnie wpływa na jej ocenę ${ }^{100}$. W innej publikacji dowodzi, że Polska czasów saskich była oazą tolerancji, a już na pewno nie była oaza nietolerancji ${ }^{101}$. Po całej tej ekwilibrystyce intelektualnej autor dochodzi do wniosku, że wprawdzie reformy pruskie były pozorne, a polskie wybitne, ale polskie pruskim dorównywały, w czym ujawnia się istota problemu. Jak pisze, reformy XVIII-wieczne w Rzeczypospolitej i Prusach miały charakter „analogiczny” i tylko w niektórych kwestiach w Polsce występowały niedostatki, jak w wypadku zmniejszenia wpływu religii i Kościoła na sferę publiczna. Aczkolwiek i tu Jacek Staszewski wskazał na prymasa Michała Poniatowskiego jako reprezentanta „polskiego józefinizmu”,

${ }_{98}$ M. Bobrzyński, dz. cyt., t. 2, s. 272.

99 Tamże, s. 275.

100 J. Staszewski, Absolutyzm oświecony..., s. 203-211; J. Gierowski, Kilka uwag o absolutyzmie..., s. 199-207; T. Cegielski, Absolutyzm w Prusach i Austrii, w: Europa $i$ świat w epoce oświeconego absolutyzmu, red. J. Staszewski, Warszawa 1991, s. $270-325$.

101 J. Staszewski, Z listy najczęściej spotykanych błędnych mniemań na temat czasów saskich, „Przegląd Humanistyczny”, t. 40, 1996, nr 1, s. 160-161. 
w czym bardzo się zagalopował ${ }^{102}$. Stanisław Salmonowicz słusznie skonstatował, że sam fakt absolutyzmu władzy utrudniał wielu autorom docenienie pozytywnych zmian i prowadził do apriorycznego odrzucenia sukcesów. Zwrócił też uwagę, że kierowanie się w ocenie formy państwa jedynie sytuacją chłopa pomija inne kluczowe reformy, ale przecież i w zakresie położenia włościan sytuacja w Prusach i Austrii ulegała znacznej poprawie ${ }^{103}$. W tym czasie w Polsce paraliżujacy lęk przed absolutum dominium blokował możliwość reform państwa, od wzmocnienia armii poczynając ${ }^{104}$. Samuel Pufendorf nie bez racji więc pisał, że w Polsce „każdy ma wzgląd tylko na swoje sprawy. Polacy odrzucają dobre rady, każdy żyje wedle swojego kaprysu i nie chce podlegać nikomu. Chwala się zuchwale prawem wybierania króla przez elekcję, a jego rozkazom okazuja posłuszeństwo tak długo, jak długo mają ochotę"105. Trzeźwa analiza sytuacji każe stwierdzić ogromne zaległości i niedorozwój Polski wobec Prus w zakresie instytucji nowoczesnego państwa, potem zaś szukać można licznych usprawiedliwień jak wskazanej dawno przez Klausa Zernacka tzw. negatywnej polityki Prus wobec Polski ${ }^{106}$.

Moim zdaniem apologetyczne wobec Sarmatyzmu tendencje w historiografii współczesnej maja w jakimś stopniu charakter zastępczy i wynikaja z faktu, że rozwój kapitalizmu przypadł w Polsce na czas rozbiorów. Nie można opiewać i „wychwalać” (W. Gombrowicz) rozkwitu kapitalizmu. Trzeźwi historycy poprzestaja na zachwytach nad potęga Polski w wieku XVI, pozostali nie potrafią przestać i później. Skłonności apologetyczne wobec Sarmatyzmu biorą się też z naturalnej idiosynkrazji na tle komunizmu od lat 80., która doprowadziła do emocjonalnego zakwestionowania całej tradycji oświeceniowej, bezzasadnie uznawanej za fundament ideologii komunistycznej. Doprowadziło to do groteskowej sytuacji, w której „ciemny” okres saski zaczęto wychwalać jako czas reform, a reformatorskie czasy stanisławowskie uważać za epokę zdrady i upadku. Tymczasem w rzeczywistości już Emanuel Rostworowski analizował niezwykle światłe i rzadkie u nas poglądy ostatniego króla Polski na kwestię włościańska, zmierzające

102 J. Staszewski, Absolutyzm oświecony..., s. 211.

103 S. Salmonowicz, Czy istniat Oświecony Absolutyzm..., s. 336.

104 A. Grześkowiak-Krwawicz, Regina Libertas. Wolność w polskiej myśli politycznej XVIII wieku, Gdańsk 2006, s. 189-214.

105 S. Pufendorf, Siedem ksiag o czynach Karola Gustawa króla Szwecji, Warszawa 2013, s. 36.

${ }^{106}$ K. Zernack, Preußen - Deutschland - Polen. Aufsätze zur Geschichte der deutsch-polnischen Beziehungen, Berlin 1991. 
do potrzeby stopniowego uwolnienia chłopów (1790), ze świadomością trzechsetletniego zapóźnienia Polski wobec Zachodu, z czym wszakże nie mógł się on przesadnie afiszować z uwagi na brak realnej władzy i poglądy wpływowych poddanych. Natomiast był on też przeciwny nagłemu i powszechnemu uwłaszczeniu, które porównywał do nagłego uwolnienia dzieci w szkole od obowiązku uczenia się, co skończyłoby się powszechnym nieuctwem. Projekty zniesienia poddaństwa powstały też w Stronnictwie Patriotycznym ${ }^{107}$. Należy jednak mieć świadomość, że reformy epoki stanisławowskiej rozgrywały się za późno i były za słabe, że w krajach absolutystycznych zrobiono znacznie szybciej i więcej. Maria Bogucka chwali Konstytucję 3 Maja za uznanie w chłopie obywatela, z powodu jednego bardzo enigmatycznego zapisu, wstawionego tam zresztą na życzenie króla, o wzięciu chłopów pod ochronę prawa. Wawrzyniec Surowiecki słusznie charakteryzował to osiagnięcie w 1812 r.: „Te dobrodziejstwa nie ugruntowane na żadnych pewnych przepisach nie ukazywały wielkiej pociechy dla włościan"108. W Prusach nie trzeba niczego domniemywać i naciagać, bo Landrecht po prostu w dziesiątkach zapisów wprost mówił, że wszyscy obywatele, i to również kobiety (!), niezależnie od przynależności stanowej też i chłopi sa równi wobec prawa. Co oczywiście jeszcze nie oznacza, że było to realizowane jak należy ${ }^{109}$.

Przy ogólnym zachwycie Sarmatyzmem wyjątkowy realizm zachowali historycy poznańscy. Witold Molik z najgłębszym sceptycyzmem odnosił się do pochwał szlachty, a także zapewnień i przysiag innych badaczy o jej wybitnej przedsiębiorczości, wskazując, że dopiero wiek XIX przyniósł stopniowy i bynajmniej nie powszechny proces „farmeryzacji” szlachty wielkopolskiej, w którym zaczęła ona przyjmować mentalność kapitalistyczną i zanikał duch utracjuszowski. Podobnie Lech Trzeciakowski wskazywał na wpływ uczenia się od rozbiorcy Polaków zaboru pruskiego na zmiany mentalności w prowincji, różnicujące stopniowo różne zabory ${ }^{110}$. Uczeń Adama Skałkowskiego Stanisław

107 E. Rostworowski, Legendy $i$ fakty XVIII w., Warszawa 1963, s. 419-424; M. Bogucka, Między obyczajem a prawem..., s. 41; D. Rolnik, dz. cyt., s. 83.

${ }_{108}$ W. Surowiecki, Moje lekcje statystyki dawane w 1812/1813, w: tenże, Wybór pism, s. 445.

109 Tamże, s. 41; Allgemeine Landrecht für die Preussischen Staaten von 1794, oprac. H. Hattenhauer, Berlin 1996, s. 444, par. 147-148.

${ }^{110}$ L. Trzeciakowski, Społeczeństwo polskie w oczach Otto von Bismarcka, KH, t. 100, 1993, nr 4, s. 166; L. Trzeciakowski, Ksztattowanie sie mentalności Polaków zaboru pruskiego, w: tenże, $W$ kręu polityki. Polacy-Niemcy w XIX w., red. K.A. Makowski, W. Molik, Poznań 2002, s. 115-134; W. Molik, Życie codzienne ziemiaństwa w Wielkopolsce $w$ XIX i na poczatku XX wieku. Kultura materialna, Poznań 1999, 
Wasylewski pisał publicystycznie i brutalnie: „Człowiek XIX wieku musiał zakasać rękawy do ogromu pracy, jaka go czekała. Zrozumiał, że nie może nadal istnieć jako pasożyt, jako truteń i wieszak bezużyteczny na kolorowe fatałachy". Cechy Wielkopolan - zdaniem Wasylewskiego - to karność, rządność punktualność umiejętność pracy zespołowej, w porównaniu z tym Galicja to nędza, a Kongresówka - bałagan ${ }^{111}$.

\section{Rozbiory samozawinione}

Rozbiory z powodu nierządu przepowiadał Polsce już Piotr Skarga, potem wracano do tego po wielokroć w XVII i XVIII w., więc nie mogło być zaskoczenia i później ${ }^{112}$. Rdzeniem trzeźwej oceny Polski sarmackiej w naszej historiografii i przyczyn jej upadku w części aspektów była dawna myśl historyczna „szkoły krakowskiej”, przede wszystkim jej głównych przedstawicieli Michała Bobrzyńskiego, Józefa Szujskiego, i Waleriana Kalinki. Wbrew temu, co się często zdaje, jej przedstawiciele nie kwestionowali nigdy haniebnego charakteru rozbiorów. Józef Szujski pisał o bezwstydnym gwałcie, zdradzie i grabieży, bo dokonały się, kiedy Polska podnosiła się z upadku i ukazywała, że stać ja na naprawę. Polska nie jest winna rozbiorów wobec Europy, ale nie rozgrzesza to narodowego sumienia ${ }^{113}$.

Michał Bobrzyński wskazywał, że i dzisiaj obowiązujący w opinii publicznej pochlebny obraz Sarmaty jest całkowicie fałszywy: „Był to Polak oczywiście z podgoloną czupryna, w kontuszu i przy karabeli, dosiadający dzielnie rumaka, śpieszący na każde zawołanie na pomoc ojczyzny, rozbijający długim proporcem ściśnięte zastępy wrogów, katolik zapisany do szkaplerza i odmawiający gorliwie koronkę, cnotliwy i przykładny w życiu domowym, choć rączy do pałasza za przycinek, to topiący $\mathrm{w}$ pucharze węgrzyna sasiedzkie niesnaski, dumny ze swego szlacheckiego klejnotu i szlacheckiej równości, wychowany w konwikcie zakonnym, ogładzony na dworze pańskim, oparty w palestrze, mówiący płynnie po łacinie, wymowny przy każdej uroczystości, w sądzie i na sejmiku, Kato w trybunale, szanujący majestat królewski, walczący w obronie wolności i wiary, a na koniec rzecz dziwna, nic przy tym

s. 11-13, 238-240, 257-262, 281-316; tenże, Rozrzutność i oszczędność ziemiaństwa polskiego w zaborze pruskim $w$ XIX $i$ na poczatku XX wieku, w: Rozrzutność $i$ skapstwo $w$ tradycji kulturowej i rzeczywistości, red. J. Tazbir, Kraków 2005, s. 133-155.

111 S. Wasylewski, Życie polskie w XIX wieku, Warszawa 2008, s. 24.

112 W. Konopczyński, Konfederacja barska, t. 1, Warszawa 1991, s. 25.

113 J. Szujski, Dzieje Polski, w: tenże, Dzieła, t. 4, Kraków 1894, s. 415. 
nie mówiono, czy też ten ideał Polaka płaci regularnie podatki [...] $\mathrm{Z}$ takiego bezdennego fałszu wywieść nas może i powinna historia"114. Bobrzyński zupełnie nie rozwodził się nad wspaniałym polskim zamiłowaniem do wolności, ale mówił wprost, jakie tu były skutki: „Wybierano króla bezradnego i pozbawionego wszelkiej władzy, wprowadzono liberum veto uniemożliwiajace jakąkolwiek reformę, bo każda reforma narusza czyjeś interesy, złota wolność służyć miała tylko za płaszcz innemu dążeniu, powiedzmy wprost materializmowi i prywacie. Złota wolność pozwalała usuwać się od obowiazków wobec ojczyzny, od wojska i od podatków a resztki skarbu publicznego obdzierać [...] Złota wolność wmówiwszy w siebie, że katolicyzm jest najsilniejszą obrona i tarcza, wystapiła z nietolerancją innowierców, uważając ich za żywioł niebezpieczny nie państwu i porządkowi publicznemu, ale tej równości i jednostajności myśli, która była warunkiem wolności. Złota wolność nienawidziła, kto czy charakterem swoim, czy rozumem, czy nowa myśla ponad tłumy wznieść się ośmielił i strącała go z jego wyżyny [...] Złota wolność była przede wszystkim wolnościa szlachecka, a więc przywilejem jednego stanu, który pociagnął za sobą poniżenie miast a niewolę wiejskiego ludu [...] Lud wiejski stracił już zupełnie opiekę prawa wobec swych panów, stracił wolność swą osobistą. Szlachcic na jednej wiosce dzierżył nad nim prawo życia i śmierci, ścigał zbiegłych włościan i do swej gleby przykuwał, szlachcic widział w nim maszynę robocza, na która tyle pańszczyzny nakładał, ile jej fizyczne siły udźwignać zdołały. Łagodność charakteru właściwa Polakom, dawny patriarchalny obyczaj, na koniec religia chrześcijańska była jedyną tarczą wieśniaka, którego zupełnie opuściło prawo”11. „Pomimo zasady równości obywatelskiej, pomimo hasła "szlachcic na zagrodzie równy wojewodzie» szlachta polska w XVIII wieku traci wpływ rzeczywisty na sprawy publiczne, przestaje być samoistnym politycznym czynnikiem, wszystkim odtąd w Polsce jest oligarchia" ${ }^{116}$.

Walerian Kalinka zwracał uwagę, że z perspektywy wizji całości dziejów Polski Bobrzyński najobszerniej ukazał budujace stulecia XV i XVI, natomiast tylko w niezbędnym rozmiarze „odstraszajacy przykład” wieków XVII i XVIII ${ }^{117}$. Kalinka słusznie zarzucał autorowi Dziejów amoralizm, że wzorem niemieckiej szkoły historycznej interesuje go tylko sukces, siła i powodzenie, a przegrani nie maja u niego racji

${ }_{114}$ M. Bobrzyński, dz. cyt., t. 2, s. 360-361.

115 Tamże, s. 181-185.

116 Tamże, s. 186.

117 W. Kalinka, O ksiażce profesora M. Bobrzyńskiego dzieje Polski w zarysie, Kraków 1879, s. 6. 
bytu. Niewątpliwie Bobrzyński był w tym dzieckiem okrutnego stulecia Darwina, Spencera i Nietzschego. Bobrzyński to jednak rozumiał nie socjaldarwinistycznie, a chrześcijańsko, rozumnie i zdrowo, odnosząc do elit szlacheckich, kierujacych krajem, a nie warstw niższych niemających wówczas wpływu na swoje losy ${ }^{118}$. Zarazem Kalinka referuje wspieranie przez Bobrzyńskiego stylu bismarckowskiego i nowożytnego „państwa biurokratycznego”, które daje impuls społeczny, jak francuskie i niemieckie, prowadząc do socjalizmu. To państwo wartościuje i hierarchizuje w ten sposób, że pozostawienie rozwoju społecznego samym obywatelom uważa za „średniowieczne” i anachroniczne. Kalinka wskazywał na przeciwstawne wzory: angielski i północnoamerykański1 ${ }^{119}$. W książce o Stanisławie Auguście autor dowodził, iż sami sobie jesteśmy winni swego upadku, a rozbiory były dla nas sprawiedliwa pokutą. Hasło Polski Chrystusa Narodów ksiądz Kalinka nazywa bluźnierstwem i chorobliwym samouwielbieniem, jeszcze gorzej ocenia pomysł, że Polska ma nieść chrześcijaństwo w świat ${ }^{120}$. „Zaprawdę $\mathrm{w}$ tym naszym gospodarstwie narodowym podobni jesteśmy do człowieka, co układając swój budżet, nie tylko niewątpliwe i spodziewane dochody jak najwyżej oznacza, a nie chce wcale spisać swoich długów, ani przewidzieć wydatków i cóż dziwnego, że nim rok minie spotyka go niedobór i że co rok część jego majątku przejdzie w obce ręce"121. Jak dowodził, przyczyna polskich problemów były niedostatki narodowego charakteru, jak dominujący wśród elit typ pyszałków typu Zborowskiego i Zebrzydowskiego. Naród polski w uszanowaniu dla jednostki, dla szlachcica, w antagonizmach i walkach o interesy koterii, zaniedbał całkowicie siłę państwa ${ }^{122}$. Polska ówczesna, dowodzi Kalinka, stała się w reformującej się Europie pośmiewiskiem i nikt po jej rozbiorze nie myślał za nia przemówić ${ }^{123}$. Gdzie indziej Kalinka dowodził, że szlachta wydelikacona zbytkiem, zajmowaniem się głównie życiem salonowym, tańcami i damami, zatraciła bojowego ducha, który zachował się u ludu. Do tego dochodził brak posłuchu i nieufność do wszelkiej władzy, sprzedajność, korupcja na niespotykaną skalę dokonywana przez dwory zagraniczne ${ }^{124}$.

118 Tamże, s. 11.

119 Tamże, s. 15-16.

${ }^{120}$ W. Kalinka, Ostatnie lata panowania Stanisława Augusta, cz. 1, Kraków 1891, s. $5-7,10$.

121 Tamże, s. 12.

122 Tamże, s. 16-17, 22-23.

123 Tamże, s. 23.

${ }^{124}$ W. Kalinka, Sejm Czteroletni, t. 1, Warszawa 1991, s. 71-72, 251-253. 
Józef Szujski bynajmniej nie pomijał winy Fryderyka II i innych zaborców, ale nacisk kładł na „narodowe wady”, słabości ustrojowe i brak reform Polski sarmackiej. Grzechy narodu, czyli szlachty, najbardziej ujawniły się w wieku XVII: „pogardzanie rządem, nierząd i pogarda bliźnim, uciemiężenie ludu". Liberum veto oznaczało upadek rozumu politycznego i zablokowanie reform społecznych. Dominowały „ciasne szlacheckie przywileje”, „kastowy egoizm”125. Wskazywał, że jeszcze Kazimierz Wielki opiekował się chłopami i starał o zachowanie równowagi społecznej w Polsce, ale już za Ludwika Węgierskiego szlachta zaczęła dominować ${ }^{126}$. „Wyłączenie stanu włościańskiego z organizmu politycznego zemściło się na nas krwawymi konsekwencjami" ${ }^{27}$. Gdy w XVI w. w Europie dokonywało się budowanie nowoczesnego państwa, w Polsce ono zaczęło się rozpadać, a lud wiejski znikną jako podmiot prawa. Kiedy na Zachodzie postępy robiła laicyzacja, u nas w czasach saskich zaczęła się nietolerancja. Pisze to konserwatysta Szujski - najświetniejsza była umysłowość polska czasów renesansu - potem przyszedł regres: „Szlachta w przeciwieństwie z Europa Zachodnia powróciła do wiary, ciemnoty i zabobonności średniowiecznej, powróciła dlatego, że reformacja nie pozostawiła na niej tych śladów”. Ale nie jest to „katolicyzm prawdziwy” pisze Szujski, przecież katolik. „Jezuici objąwszy ster narodowego wychowania, odebrali Polsce to zdrowe i święte poczucie prawdziwej religii, miłości, względności, zepsuli krew naszą nietolerancją religijna, odebrali nam śmiałość spojrzenia rycerskiego, które świat cały obejmowało. Odebrali nam ducha reformy społecznej, ducha śmiałego wypowiadania prawdy [...]”128. Wiek XVIII, czasy oświecenia: „Jakiegoż losu mogła się w tym wieku spodziewać zmącona zabobonno-katolicka Polska [...] Polska już nie włada swoim losem" 129 .

Czasy saskie, to epoka zrywanych sejmów i sejmików, przekupstwa przez magnatów, których potęga bardzo urosła i obcych posłów. Pisał Szujski o „drobnych prowincjonalnych cezarach”, którzy kłócili się wzajemnie, nie myśląc o publicznym interesie i zaczęli rządzić kawałkami Polski ${ }^{130}$. Kulało jezuickie szkolnictwo, piśmiennictwo było odpowiednio

${ }_{125}$ J. Szujski, Kilka prawd..., w: tenże, Dzieła, ser. 3, t. 1, Kraków 1885, s. 275-276.

126 J. Szujski, Szlachta i inteligencja, w: tenże, Dzieła, ser. 3, t. 1, Kraków 1885, s. $10-11,14$.

127 Tamże, s. 14.

128 J. Szujski, Rzut oka na stanowisko Polski w historii powszechnej, w: tenże, Dzieła, ser. 2, t. 5, Kraków 1885, s. 18, 28.

129 Tamże, s. 33.

130 J. Szujski, Dzieje Polski..., s. 364. 
wsteczne. Ostatecznie: „Na tej podstawie ugruntowała się swoboda i bezmyślność czasów Augusta, której pamięć uwieczniło znane przysłowie: Za króla Sasa jedz pij i popuszczaj pasa. Przysłowie to maluje nam wybornie obyczaj narodowy ówczesny. Cała bujność natury szlacheckiej, cała jej burzliwość postradawszy plac popisu na sejmach i wojnie, poszła tyrać się w hulankach i pijatykach domowych, sejmikowych, trybunalskich [...]. Rok cały upływał błogo wśród rozmaitości zebrań obywatelskich, przeplatanych świętami kościelnymi, z skrupulatnie obchodzonymi nabożeństwami, które po mszy wiodły za soba sute obiady, a po nieszporach huczne pijatyki i tańce. Malownicze to życie podało naszym poetom i powieściopisarzom bogatą skarbnicę podmiotów do traktowania i potworzyło dzieła, które aż nadto złagodziły jego ekonomiczna, moralna i polityczną ujemność. Historia musi je bezwzględnie potępić, jako nieprodukcyjne, próżniacze i bezjutre. Tysiączne świadectwa dowodza, że wśród tego nieopatrznego życia podupadło gospodarstwo a wzmógł się ucisk ludu wiejskiego [...]”131. Historyk przypominał druzgocące dla Sarmacji i szlachty sądy Zygmunta Krasińskiego: „Byliśmy najniepewniejszym, najbłędniejszym, najbledszym, że tak powiem narodem w historii i ludzkości”. Szlachta „nie nauczyła się życia, w letargu żyła, a obudzenie się było śmiercia”"132. „Język polski dla umarłego łacińskiego, potem dla żyjącego francuskiego porzucony, literaturka z konceptów włoskich, z maksym Cycerona, z wierszyków francuskich, $\mathrm{z}$ ballad niemieckiego wyarlekinienia. W niczym geniuszu, w niczym życia, po śmierci dopiero żyć się nam zachciało. Że wojen religijnych u nas nie było, to tylko dowód, że nikt nie wierzył w nic mocno. $\mathrm{O}$ to, w co ludzie wierzą biją się [...]. Naród Polski był zawsze leniwy do wojny, do pospolitego ruszenia. Lubił wygódki - ale za to fanfaron wielki [...] Jedyną tradycją była u nas swawola [...] nawet bezinteresowność jest u nas lenistwem, szlachetność lekkomyślnym dogadzaniem sobie, kosztem dobra publicznego"133.

Dostrzegał nieudolność i sarmackiego ducha, sejmikową krzykliwość i ociężałość narodu w próbach zmian i oporu zaczęty z konfederacją barska, która „prócz zamieszania nic nie sprawia, ginie”134. Stopniowo postępowały wszakże reformy, zmiany podnoszenie z upadku, uwieńczone Sejmem Wielkim. „Szał cywilizacji zachodniej” zastapił dotychczasowe status quo i liberum veto odrzucające wszelką zmianę. Za późno jednak,

131 Tamże, s. 405-406.

132 J. Szujski, O młodszości naszego cywilizacyjnego rozwoju, w: tenże, Dzieła, ser. 2, t.7, Kraków 1888, s. 361-366.

${ }^{133}$ Za: tamże, s. 366-367; J. Szujski, Rzut oka..., s. 33.

134 J. Szujski, Dzieje Polski..., s. 415. 
mimo że dzielnie, goraczkowo, aby nadrobić stracony czas i do tego spuścizna wieków ciążyła „ołowiano u stóp”. Starania te zakończone zostały „nieudolnym” powstaniem 1794 r., gdzie szlachta angażowała się bez wiary ${ }^{135}$. Ostatecznie więc, jak pisał: „Jeżeli naród jako państwo upadł, to z własnej winy, jeżeli powstanie, to własna praca, własnym rozumem, własnym duchem. Jest to toż samo jakbym powiedział, że naród upadł z woli Bożej ukarany, powstanie zaś z tejże woli, odrodzony [...]. Słowo to moje nie wyklucza winy obcej przy upadku [...]"136.

Anarchia i brak politycznego rozumu były - zdaniem Szujskiego głównym powodem upadku Polski, ale dostrzegał, że nasze wady ustrojowe podzielały inne kraje regionu, jak Czech i Węgry, również ukarane za brak reform ${ }^{137}$.

Najsurowiej atakował Szujski romantyczna nieracjonalność ducha liberum conspiro: „Obłędzie, który mniemasz, że dosyć jest chcieć wypędzić nieprzyjaciół, że dosyć jest zrobić konspiracyjkę jedną lub druga, aby być wolnym i niepodległym, wynieś się z ziemi naszej, opuść ja na zawsze, bo sprowadzasz tylko klęski bez granic, bo policzone już dni twoje, które z woli Bożej spędzałeś między nami, bo dokonałeś już swego i złożyć nam Cię przychodzi do grobu z słowem miłości i przebaczenia chrześcijańskiego. Wiecie, co znaczy stać się wolnym? Stać się wolnym to znaczy zdolnym utworzyć rząd i dokonać reorganizacji społeczeństwa. A rząd ten nie może być żadną arlekinadą rządu, ale rządem organicznym, obejmującym wszystko, a reorganizacja nie może być destrukcja, ale budowaniem"138.

Wbrew potocznej opinii nawet i główny przedstawiciel szkoły warszawskiej nie był bynajmniej zachwycony Polską sarmacką i dostrzegał brak patriotyzmu szlachty i brak reform prowadzących do nowoczesności ${ }^{139}$. Jak słusznie zwrócił uwagę Roland Gherke, szkoła warszawska w osobach zarówno Tadeusza Korzona, jak i Władysława Smoleńskiego uznawała winy własne Rzeczypospolitej, a jedynie w większym stopniu akcentowała winę zaborców ${ }^{140}$.

Mamy przecież u Korzona sądy druzgocące na temat Polski szlacheckiej, jak gdy pisze: „wobec nadciagających z zagranicy nawałnic

135 Tamże, s. 416.

136 J. Szujski, Kilka prawd..., s. 274; tenże, Rzut oka..., s. 33.

137 J. Szujski, O mtodszości..., s. 361-362.

138 J. Szujski, Kilka prawd..., s. 279.

139 M. Krzoska, Teilungserfahrungen und Teilungsbildung: die Historiographie der Teilungen Polen-Lithauens (1795-2011), w: Die Teilungen Polens-Lithauen, red. H.J. Bömelburg u.a., Osnabrück 2013, s. 42-44.

${ }^{140}$ R. Gherke, dz. cyt., s. 209. 
sfery rządzące w Polsce upadającej ujawniły ogrom wstrętnego zepsucia, a mała stosunkowo dozę przezorności, energii, poświęceń, mało umysłów uzdolnionych do pojmowania polityki i prawa państwowego, a jeszcze mniej charakterów politycznych"141. O czasach saskich mówił Korzon najsurowiej: „boć to było najciemniejsze ze wszystkich pokoleń, jakie zna historia, przynajmniej od Kazimierza Wielkiego [...] wśród anarchii szlachcic podeptał już plebejuszów i przywłaszczył sobie prawo do życia i śmierci nad chłopem [...] Polska stała się anomalią w szeregu państw europejskich i wysadzała się jakby na przekorę, aby z duchem wieku XVIII być w nieustannej sprzeczności [...] pół wieku takiego życia podało Polskę w pośmiewisko u wszystkich narodów, że Polak za granicą wstydził się swego narodowego miana". Czasy stanisławowskie to dla Korzona tylko czasy stopniowego przebudzenia narodu ${ }^{142}$.

Z kolei wybitny twórca poznańskiej szkoły historycznej Adam Skałkowski uważał bardzo zdecydowanie, że „śmierć Augusta III zamknęła przydługa pijacką stypę” w trakcie której, „od lat kilkudziesięciu w bezładzie, sobkostwie, lenistwie ducha, grzebano szczęty niepodległości”143. Na progu rządów ostatniego króla Rzeczypospolitej „ogół szlachecki zapił lub zagubił rozum i sumienie. Gdy trzeźwiał czuł się nieswojo"144. Reformy stanisławowskie prowadzone były „nie po myśli pokolenia doby saskiej, wierzącego, iż Polska właśnie nierządem stoi, a istnieć nadal może tylko w stanie niemocy anarchicznej (jako sasiadom dogodna w swej bezsilnej anarchiczności). Ogół szlachecki, idąc na pasku możnowładców śmiertelnie skłóconych z familia podzielił ich wzgardą do parweniuszów Poniatowskich; obojętnie odnosił się do najpożyteczniejszych starań króla, jak: podniesienie miast przez Komisję Dobrego Porządku, czy założenie korpusu kadetów. Raził go dwór na modłę zagraniczną [...]”. Sądził wszakże, że ogół był moralnie zdrowszy od swoich przodków, a występek szerzył się wśród „maruderów jezuickiego wychowania"145.

Później - pisał Skałkowski - tak jak wynoszono Kościuszkę i budowano jego legendę, tak samo w pognębianiu pamięci Stanisława Augusta Poniatowskiego „wśród ogółu inteligencji ustalił się sąd ujemny bezwzględnego potępienia Stanisława Augusta"146. Występowała

${ }_{141}$ T. Korzon, dz. cyt., t. 3, Kraków-Warszawa 1897, s. 1-2.

142 Tamże, s. 32-35.

143 A. Skałkowski, w: Polska, jej dzieje i kultura, t. 2, Warszawa 1927, s. 216.

144 Tamże, s. 219.

${ }_{145}$ A. Skałkowski, Rehabilitacja Stanistawa Augusta, „Problemy” 1947, nr 4, s. $220-221$.

146 Tamże, s. 219. 
„patriotyczna lub prostoduszna chęć uwolnienia narodu od strasznych zarzutów prywaty, nie rozumu i bezrządu, które pogrążały Rzeczypospolita w niemocy, wydając ją na łup wrogom. Znalazłszy kozła ofiarnego, strząsnąwszy nań grzechy, można było na tułactwie dojść do uwielbienia nieszczęść swoich jako powtórzenia męki Pańskiej”147.

Trzeba powiedzieć, że poglądy Skałkowskiego bardzo różniły się od zapatrywań jego mistrza. Szymon Askenazy uważał, że praca historyka ma wymiar patriotyczny i powinna wzmacniać i krzepić swym optymizmem. Forsował więc pogląd, że to agresja zewnętrzna doprowadziła do upadku kraju, bo wprawdzie Polska była słaba, ale i inne kraje miewały kryzysy, a przecież nie upadły ${ }^{148}$.

Kolega Adama Skałkowskiego z seminarium Szymona Askenazego w Lwowie, Władysław Konopczyński, miał nie mniej surowy osąd Sarmatyzmu. Jak pisał, w XVII w. szlachta broniła się przed wszelkimi zmianami i reformami, które mogłyby wzmocnić władzę królewska w obawie przed absolutum dominium. „Jest syta, więc nie chce żadnych nowości" ${ }^{149}$. Magnateria w ciagu XVII w. odgrywała rolę coraz większa, słabła rola i siła wszystkich pozostałych stanów. Podupadły miasta, w porównaniu z wiekiem XVI Polska odstawała coraz bardziej od Zachodu, zwłaszcza słabością armii, co było coraz bardziej niebezpieczne $^{150}$. Absolutyzm Zachodu od ok. 1700 zaczynał brać w swoje ręce szkolnictwo, rozumiejąc „państwowe znaczenie wychowania”, w Polsce dominowali anachroniczni jezuici, których negatywne znaczenie wprawdzie przeceniano, ale jednak „kształcili wyznawców, bojowników Kościoła, nie kształcili obywateli”. Czasy saskie przyniosły upadek, zwyrodnienie, bezmyślność i deprawację ${ }^{151}$. „Słabych, złamanych, niedokształconych ludzi łatwiej chwyta się zły nałóg i występek. Starsi i młodsi przesyceni wolnościa, przejęci jedną tylko troska, żeby ich nikt nie turbował w domowym groszoróbstwie i pasibrzuchostwie, bez pędu twórczego, bez głębszej samowiedzy moralnej [...]”152. „Z ciasnotą horyzontów wzmaga się po 1720 roku powszechna apatia [...] Między służalstwem na pokojach JKMości i warcholstwem na sejmiku, między blichtrem niby europejskim salonów a brudem i ciemnotą zaścianków nie

147 A. Skałkowski, Polska, jej dzieje i kultura, t. 2, s. 216.

148 M.H. Serejski, Naród a państwo w polskiej myśli historycznej, Warszawa 1977, s. 252; A. Wierzbicki, Naród - państwo w polskiej myśli historycznej dwudziestolecia międzywojennego, Warszawa 1978, s. 13-14.

149 W. Konopczyński, Dzieje Polski nowożytnej, t. 2, Warszawa 1986, s. 86-88.

150 Tamże, s. 88-89.

151 Tamże, s. 114.

152 Tamże, s. 115. 
ma miejsca na głębszą myśl ani namiętność. Dowcip statystów wysila się na pomysły, jak wystrychnąć rywala przy szafunku wakansów jak opanować trybunał lub ziemstwo, jak zerwać sejm"153. Narastało znaczenie prymitywnych form katolicyzmu praktykowanego przez szlachtę, „płytka dewocja, stawiająca kościelne praktyki wyżej od doskonalenia dusz ludzkich" i rosła pozycja duchowieństwa. Szczytowym przejawem tej formy religijności była w 1717 r. koronacja Matki Boskiej Częstochowskiej ${ }^{154}$. Konarski podsumowywał w 1761 r. sytuację kraju: „Niesława, hańba, słabość, sromota, upadek na wszystkiem całego narodu”. Pognębienie chłopów wspominaja wszyscy wybitniejsi dziejopisarze tamtych czasów, więc i Konopczyński. Jego charakterystyka umysłowości szlacheckiej wskazuje na jej całkowita jałowość i rozmiękczenie, przy czym pijaństwo i korupcja to niewątpliwe, ale najbardziej powierzchowne przypadłości. Ważne, że życie szlacheckie było rozrzedzone i kultura jej też rozrzedzona. Nie było ani ciężkiej pracy, ani walki, ani żadnej innej intensywności, „rozwinęło się lenistwo i niedbalstwo” 155 . Bohater konfederacji barskiej, ksiądz Marek Jondołowicz, nazywany „natchnionym prostaczkiem z Podola”, zajmował się cudownym leczeniem chorób i wypędzaniem szatana. Konfederaci chłopów nie traktowali jako narodu lecz „żer armatni”, o reformach społecznych myślano ze zgroza, a poddani stosownie do tego darzyli sprawę niepodległości obojętnością ${ }^{156}$.

Nie jeden Stanisław Brzozowski dostrzegał coś okropnego w sprzeczności szlacheckiego ckliwego optymizmu, zawołania „kochajmy się, sursum corda” oraz nieprzyjemnego poczucia wyższości wobec „chamów”157. Polski indywidualizm, jego zdaniem, polegał jedynie na beztroskiej wygodzie, nie angażowaniu się i zaściankowości; „Siedząc na tłustym połciu ziemi - szlachcic ufał swej szabli, pyskatości swej i sprytowi. Rozum, jako konstrukcja władających przyroda - był mu niepotrzebny [...] Nie ma narodu tak mało poszanowania mającego dla indywidualności twórczej, twardą ręką wykuwajacej sobie rozumienie świata, władzę nad nim, jak my właśnie"158. Sednem myślenia szlacheckiego było swojskie rodzinne sioło i jego sprawy: „byle Kmicic poją Oleńkę, a pan Stach Marynię - a wszystko da się przetrwać"159.

\footnotetext{
153 Tamże, s. 116.

154 Tamże, s. 117.

155 Tamże, s. 172-173.

${ }^{156}$ W. Konopczyński, Konfederacja barska..., t. 2, s. 745, 761-763.

157 S. Brzozowski, Legenda Młodej Polski. Studia o strukturze duszy kulturalnej, t. 1, Kraków 1997, s. 50.

158 Tamże, s. 78.

159 Tamże, s. 81.
} 


\section{Podsumowanie}

Punktem odniesienia mojego tekstu jest niesłusznie głośna, bo oczywista teza Jana Sowy o modernizacyjnym charakterze rozbiorów. Jej duży rezonans wynika ze znalezienia się w obiegu medialnym i pop-kulturowym, który operuje prościutkimi stereotypami, kalkami, a funkcjonujące $\mathrm{w}$ nim wyobrażenia historyczne sa nacjonalistyczne, proste, moralizatorskie i ahistoryczne. Mówiąc krótko: skoro Polska znalazła się pod zaborami w okresie kapitalistycznej modernizacji swoich zaborców, wobec tego chcąc nie chcąc tej modernizacji musiała też podlegać. Oczywiście, w wypadku czysto kolonialnej eksploatacji sytuacja byłaby inna. Najkorzystniejsza w zakresie instytucji i rozwoju cywilizacyjnego i społeczno-ekonomicznego była sytuacja zaboru pruskiego. Nie oznacza to, że pod zaborami panowały stosunki sielankowe, wprost przeciwnie, jednak te aspekty naszej historii były już badane i słusznie, w pierwszej kolejności. Tak więc w moim tekście je pomijam i ukazuję kwestię zmian pozytywnych. Równocześnie jednak w historiografii ostatnich dziesięcioleci w kontraście do okresu PRL-u zaczęto przesadnie optymistycznie oceniać sarmacka formację cywilizacyjną i społeczno-ekonomiczna. W rezultacie doprowadziło to do całkowicie karykaturalnego obrazu porównywanych ze sobą Prus i Rzeczypospolitej XVIII w. Tymczasem losy obydwu tych państw nawzajem się oświetlają i wiele o sobie mówią. Dotąd wskazywano głównie na wady Prus i zalety Rzeczypospolitej. Ja postępuję dokładnie odwrotnie, aby wskazać na luki $\mathrm{w}$ dotychczasowej narracji.

\section{Bibliografia}

Adamczyk D., Zur Stellung Polens im Modernen Weltsystem der Frühen Neuzeit, Hamburg 2001.

Bömelburg H.-J., Die Magnaten: Avantgarde des Ständeverfassung oder oligarchische Clique? Ständefreiheit und Staatsgestaltung in Ostmitteleuropa. Übernationale Gemeinsamkeiten in der politischen Kultur vom 16.-18. Jahrhundert, red. J. Bahlcke, H. J. Bömelburg, N. Kersken, Leipzig 199, s. 119133 (Forschungen zur Geschichte und Kultur des östlichen Mitteleuropa).

Bömelburg H.-J., Friedrich II zwischen Deutschland und Polen,. Ereignis- und Erinnerungsgeschichte, Stuttgart 2011.

Bömelburg H.-J., „Polnische Wirtschaft”. Zur internationalen Genese und zur Realitätshaltigkeit des Stereotzpie der Aufklärung, w: Der Fremde im Dorf. Über legungen zum Eigenen und zum Fremden in der Geschichte, red. H.-J. Bömelburg, Lüneberg 1998, s. 231-248. 
Bömelburg H.-J., Zwischen polnischer Ständesgesellschaft und preussischem Obrigkeitsstaat. Vom königlichen Preussenzu Westpreussen (1756-1806), München 1995.

Faber F., Sarmatismus. Die politische Ideologie des polnischen Adels im 16. und 17. Jahrhunderts, Freiburg im Breisgau 2013.

Gierowski J. A., The Polish-Lithuanian Commonwealth in the XVIII Century. From Anarchy to Well-Organised State, Kraków 1996

Hintze O., Preußische Revormbestrebungen vor 1806, w: Regierung und Verwaltung. Gesammelte Abhandlungen zur Staats-, Rechts- und Sozialgeschichte Preussens, Göttingen 1976.

Maczak A., Klientela. Nieformalne systemy władzy w Polsce i Europie XVIXVIII w., Warszawa 1994.

Mączak A., Nierówna przyjaźn. Uktady klientalne w perspektywie historycznej, Wrocław 2003.

Simsch A., Die Wirtschaftspolitik des preußischen Staates in der Provinz Südpreußen 1793-1806/7, Berlin 1984.

Sosnowska A., Zrozumieć zacofanie. Spory historyków o Europę Wschodnia (1947-1994), Warszawa 2004.

Straubel R., Beamte und Personalpolitik im altpreußischen Staat. Soziale Rekrutierung, Karriereverläufe, Entscheidungsprozesse, Potsdam 1998.

Dariusz Łukasiewicz

Sarmatism and Prussia in the $18^{\text {th }}$ century and the early $19^{\text {th }}$ century (Summary)

The reference point of the article is Jan Sowa's unfairly popular - being quite obvious - thesis on the modernising character of the partitions. Its great resonance derives from its circulation in the media and pop-culture, which operate on simple stereotypes and calques, while the historical ideas within it are nationalist, simple, moralising, and ahistorical. To put it shortly, Poland was partitioned in the period of capitalist modernisation of the countries annexing its territory, which is why it had no choice but to undergo the modernisation as well. Naturally, the situation would have been different in case of purely colonial exploitation. When it came to institutions and the civilisational and social-economic development, the situation of the Prussian partition was the most beneficial. This does not mean, however, that the relations with the partitioner were idyllic, quite the opposite, but this aspect of the Polish history has already been researched and rightfully prioritised. This is why the paper omits it and instead focuses on the issue of positive changes. At the same time, the historiography of the recent decades has stood in contrast to the period of the People's Republic of Poland in its overly optimistic view of the Sarmatian civilisational and social-economic formation. This led to the creation of a complete caricature of the comparison between Prussia and 
the Polish-Lithuanian Commonwealth in the $17^{\text {th }}$ century. The truth is, meanwhile, that the histories of both these countries shed light on and tell a great deal of each other. Up to now researchers have mainly indicated the disadvantages of Prussia and the advantages of the Commonwealth. The author of this paper does the exact opposite in order to indicate gaps in the narrative created so far.

Dariusz Łukasiewicz - dr hab., profesor nadzwyczajny w Instytucie Historii im. Tadeusza Manteuffla PAN, zajmuje się historia społeczno-gospodarczą, kulturową i życiem codziennym Polski i Prus w XVIII i XIX w., szczególnie na przełomie tych stuleci. Wydał i poprzedził przedmową książkę Adama Skałkowskiego, Kościuszko w świetle najnowszych badań (Warszawa 1991, 1924). Autor książek: Czarna legenda Polski. Obraz Polski i Polaków w Prusach 1772-1815 (Poznań 1995); Szkolnictwo w Prusach Południowych w epoce reform Oświeceniowych (Poznań 2004); Zło niechrześcijańskie i nieludzkie. Historia dzieciobójstwa $i$ inne studia $z$ dziejów codzienności (Poznań 2014). Jest współautorem obszernych fragmentów w syntezach Historii Pomorza (t. 2) i Historii Prus (t. 2-4). E-mail: dlukas@man.poznan.pl. 